\title{
Comparative Metagenomic Analysis of Two Hot Springs From Ourense (Northwestern Spain) and Others Worldwide
}

\author{
Maria-Eugenia DeCastro, Juan-José Escuder-Rodriguez, Manuel Becerra, \\ Esther Rodríguez-Belmonte and María-Isabel González-Siso*
}

Grupo EXPRELA, Centro de Investigacións Científicas Avanzadas (CICA), Departamento de Bioloxía, Facultade de Ciencias, Universidade da Coruña, A Coruña, Spain

With their circumneutral $\mathrm{pH}$ and their moderate temperature $\left(66\right.$ and $68^{\circ} \mathrm{C}$, respectively), As Burgas and Muiño da Veiga are two important human-use hot springs, previously

OPEN ACCESS

Edited by:

Kian Mau Goh,

University of Technology Malaysia,

Malaysia

Reviewed by:

Arisa Nishihara,

National Institute of Advanced Industrial Science and Technology

(AIST), Japan

Song Zhaoqi,

Shangqiu Normal University, China

*Correspondence:

María-Isabel González-Siso isabel.gsiso@udc.es

Specialty section This article was submitted to Extreme Microbiology, a section of the journal

Frontiers in Microbiology

Received: 01 September 2021

Accepted: 26 October 2021

Published: 26 November 2021

Citation

DeCastro M-E

Escuder-Rodríguez J-J, Becerra M,

Rodríguez-Belmonte $E$ and

González-Siso M-I (2021)

Comparative Metagenomic Analysis of Two Hot Springs From Ourense (Northwestern Spain) and Others

Worldwide

Front. Microbiol. 12:769065. doi: 10.3389/fmicb.2021.769065 studied with traditional culture methods, but never explored with a metagenomic approach. In the present study, we have performed metagenomic sequence-based analyses to compare the taxonomic composition and functional potential of these hot springs. Proteobacteria, Deinococcus-Thermus, Firmicutes, Nitrospirae, and Aquificae are the dominant phyla in both geothermal springs, but there is a significant difference in the abundance of these phyla between As Burgas and Muiño da Veiga. Phylum Proteobacteria dominates As Burgas ecosystem while Aquificae is the most abundant phylum in Muiño da Veiga. Taxonomic and functional analyses reveal that the variability in water geochemistry might be shaping the differences in the microbial communities inhabiting these geothermal springs. The content in organic compounds of As Burgas water promotes the presence of heterotrophic populations of the genera Acidovorax and Thermus, whereas the sulfate-rich water of Muiño da Veiga favors the codominance of genera Sulfurihydrogenibium and Thermodesulfovibrio. Differences in ammonia concentration exert a selective pressure toward the growth of nitrogen-fixing bacteria such as Thermodesulfovibrio in Muiño da Veiga. Temperature and $\mathrm{pH}$ are two important factors shaping hot springs microbial communities as was determined by comparative analysis with other thermal springs.

Keywords: thermophiles, extreme environments, hot springs, microbial communities, metagenomics, next generation sequencing

\section{INTRODUCTION}

Metagenomics has revolutionized microbial ecology, overcoming and complementing the traditional time-consuming culture methods. This approach has widely contributed to reveal the great microbial diversity of ecosystems previously thought to be lifeless and scarcely studied due to their irreproducible environmental conditions, such as hot springs. Nowadays, hot springs are considered ideal sites for studying the early life forms, or even extraterrestrial conditions (Konhauser et al., 2003; Pirajno, 2020). Furthermore, metabolically diverse microbial 
communities have been described in hot springs with very different physicochemical parameters (Sahay et al., 2017; Saxena et al., 2017), and some of their thermostable enzymes have been characterized as valuable biocatalysts with potential use in biotechnology and industry (Li and Liu, 2017; Ferrandi et al., 2018).

Previous studies have utilized comparative metagenomics to unveil the influence of physicochemical parameters in the diversity of thermophilic microbial communities inhabiting thermal springs (Menzel et al., 2015; Chiriac et al., 2017; Hussein et al., 2017; Sahoo et al., 2017; Mehetre et al., 2018). Among those, temperature and $\mathrm{pH}$ have been frequently identified as important factors shaping hot springs microbial populations (Chaudhuri et al., 2017; Mahato et al., 2019; Podar et al., 2020). Numerous investigations have reported a decrease in hot spring biodiversity with increasing temperature (Sharp et al., 2014; Li et al., 2015; Lavrentyeva et al., 2018). Chan et al. (2017) found that species richness and evenness in Malaysian hot springs were negatively correlated with temperature, and thus the composition of the microbial community was determined by this parameter. A significant role of temperature regulating the distribution of hot spring microbial communities was also reported in the Tibetan Plateau Geothermal Belt (China) (Guo et al., 2020) and in Odisha (India) (Badhai et al., 2015). Contrariwise, Power et al. (2018) studied 925 geothermal springs across New Zealand and determined that $\mathrm{pH}$ was the main factor influencing hot spring diversity at temperatures below $70^{\circ} \mathrm{C}$, while temperature had a significant effect on the microbial distribution at those hot springs with water temperature above $70^{\circ} \mathrm{C}$.

From all the thermal spots found across Ourense (Galicia, Northwestern Spain), As Burgas and Muiño da Veiga hot springs are located just $5 \mathrm{~km}$ away, but their waters show very different chemical and mineral composition due to the high geologic variability of the region (González-Barreiro et al., 2009; López et al., 2019). The diatom communities and the lipolytic enzyme-producing thermophiles inhabiting As Burgas have been previously investigated by traditional methods (Deive et al., 2013; Leira et al., 2017); nevertheless, the sequencing of the whole environmental DNA, known as shotgun metagenomics, has never been applied to study As Burgas or Muiño da Veiga microbiomes.

In this work, we have used metagenomics in conjunction with statistical tools to compare the microorganisms and community structure of As Burgas and Muiño da Veiga. Moreover, in an attempt to ascertain whether environmental conditions such as $\mathrm{pH}$ or temperature determine the microbial diversity and function of these nearby ecosystems, we have analyzed the functional and taxonomical profile of these geothermal springs and other geographically distant hot springs that encompass different $\mathrm{pH}$ and temperatures.

\section{MATERIALS AND METHODS}

\section{Sample Collection}

As Burgas (BW) water, with temperature $66.3^{\circ} \mathrm{C}$ and $\mathrm{pH} 7.56$ (González-Barreiro et al., 2009), was collected from As Burgas hot spring (GPS 42.334626, - 7.865332), in Ourense (Galicia, Spain) (Figure 1A). Sampling was performed directly from the spout (Figure 1B) and not from a pool or reservoir exposed to light. The water sample was stored at room temperature and processed the next day when it was filtered through a nitrocellulose filter of $0.2 \mu \mathrm{m}$ cutoff, using a bottle top filter holder (Nalgene) and a vacuum pump. Filter was stored at $-20^{\circ} \mathrm{C}$ until metagenomic DNA extraction. Muiño da Veiga (MDV) water, with temperature $68^{\circ} \mathrm{C}$ and $\mathrm{pH} 7$, was collected from a water pump (Figure 1C) located in Muiño da Veiga hot spring (GPS 42.352397, -7.909714), in Ourense (Galicia, Spain) (Figure 1A), following the same procedure described in As Burgas.

\section{DNA Extraction and Sequencing}

Total DNA was isolated from the BW filters using the Metagenomic DNA Isolation Kit for Water (Epicentre Biotechnologies), according to the manufacturer's protocol. Metagenomic DNA of both replicates was quantified using Qubit dsDNA HS Assay kit (Invitrogen) and prepared for Next-Generation Sequencing using the Accel-NGS ${ }^{\circledR}$ 2S Plus DNA Library Kit (Swift Biosciences). The amplified libraries were checked with a Bioanalyzer 2100 (Agilent Technologies), and concentrations were quantified by Qubit dsDNA HS Assay kit (Invitrogen). Paired-end sequencing of the metagenomic DNA libraries was performed with $2 \times 300$ bp using the MiSeq sequencer (Illumina, San Diego, CA, United States) at San Diego State University. Similarly, metagenomic DNA from MDV was isolated from the filters using the Metagenomic DNA Isolation Kit for Water (Epicentre Biotechnologies), according to the manufacturer's protocol. MDV metagenomic DNA was sequenced using the Illumina Hi-seq 1500 platform with $2 \times 100$ base read length by the sequencing services of Health in Code (A Coruña, Spain).

\section{Taxonomic Distribution and Statistical Analysis}

Illumina reads were treated with PRINSEQ software (Schmieder et al., 2011) for quality control, removing all artificial duplicate reads and reads shorter than 60 base pairs. High-quality unassembled reads of both samples were uploaded into the Metagenomics Rapid Annotation using the Subsystem Technology (MG-RAST) v4.0.3 server (Meyer et al., 2008). BW and MDV metagenomes are publicly available under the accession numbers mgm4709018.3 and https://acortar.link/ 9uzzaS, respectively. MG-RAST server was used to assign the taxonomic profile of the metagenomic reads, with a maximum $e$-value of $1 \mathrm{e}^{-05}$, a minimum identity of $60 \%$, and a minimum alignment length of $15 \mathrm{bp}$. The statistical analysis of the different taxonomic levels generated on MG-RAST was performed using the Statistical Analyses of Metagenomic Profiles (STAMP) (Parks et al., 2014) software. The significance of differences between proportions in the taxonomic distribution of BW and MDV samples was performed using the two-sided Fisher's exact test, with the Newcombe-Wilson confidence interval method. Because $p$-values were not uniformly distributed, BenjaminHochberg false discovery rate was applied for correction. Results 

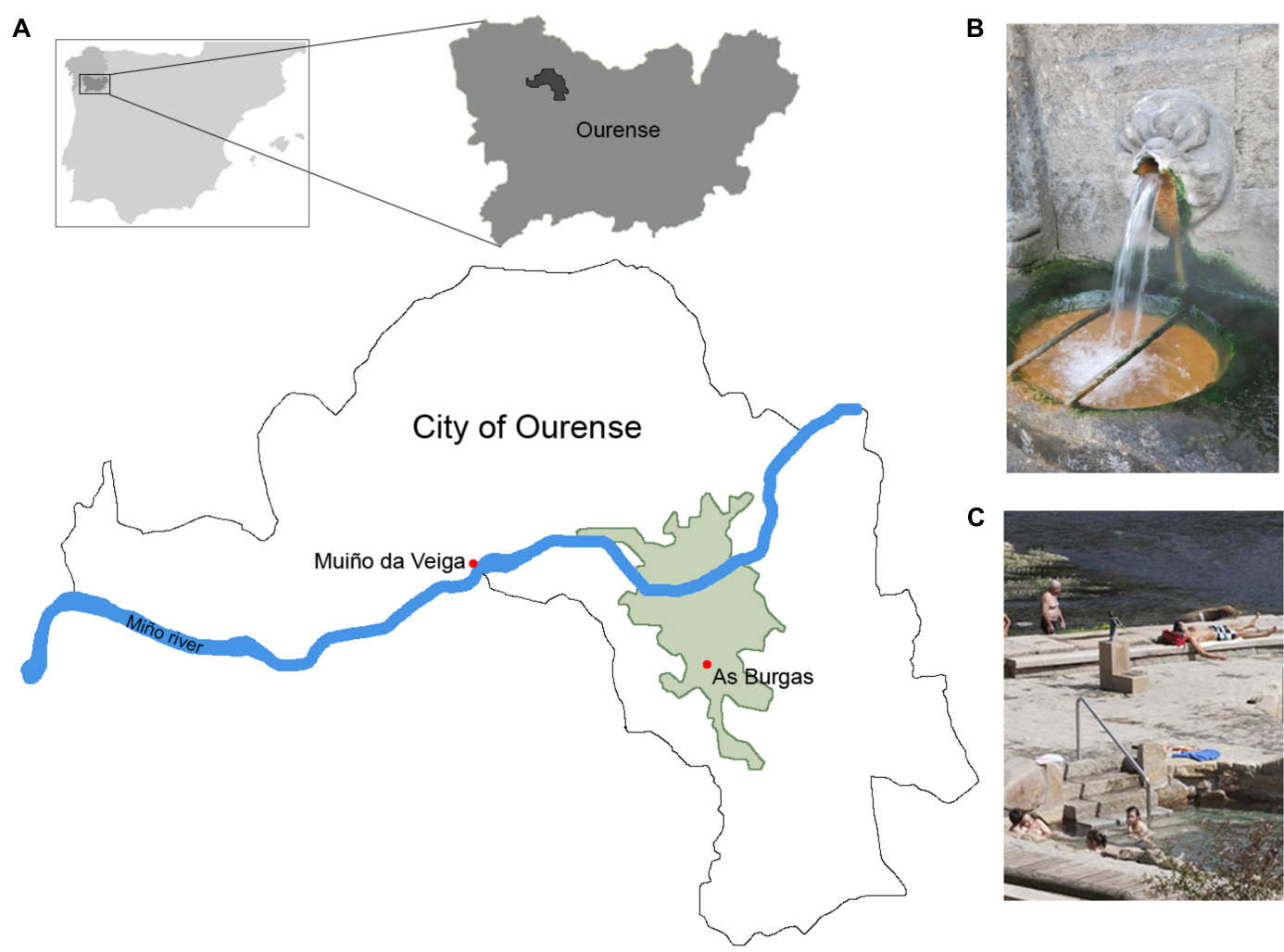

FIGURE 1 | Details of As Burgas and Muiño Da Veiga hot springs. Geographical location (A), As Burgas water spout (B), and Muiño da Veiga water pump (C).

with $q<0.05$ were considered significant. A difference of at least $1 \%$ and a twofold ratio between proportions was applied.

\section{Functional Analyses}

Functional analyses were performed using the SEED subsystems annotation in the MG-RAST, with a maximum $e$-value of $1 \mathrm{e}^{-05}$, a minimum identity of $60 \%$, and a minimum alignment length of $15 \mathrm{bp}$. The functional profiles generated by MG-RAST were statistically analyzed in the STAMP, with the same procedure and parameters described previously for the taxonomic analyses.

\section{Metagenome Sample Selection for Comparative Metagenomics}

Apart from BW and MDV metagenomes, six other hot spring metagenomes were selected for the comparative analysis. To reduce the "type of sample" influences, this study included only hot spring water samples. All the samples selected are listed in Table 1 and publicly available on MG-RAST. The metagenomic sample of MDV is part of a present unpublished study from our group and was selected for its proximity to As Burgas hot spring, as both of them are located only a few kilometers away in the same Galician region (Ourense, Spain).

Taxonomic and functional profiles of the different samples were extracted from the MG-RAST. All of them are hot spring water samples that contain unassembled raw metagenomic reads in order to obtain information about the abundance of the sequences and, therefore, to be able to properly compare between samples. For each metagenome, sequence counts on MG-RAST were standardized against the total number of hits to remove bias in different sequencing efforts and library size.

\section{RESULTS AND DISCUSSION}

\section{DNA Extraction and Sequencing}

After the quality control, 893,557 and 27,113,937 sequences with a total of $253,083,221$ and $3,968,584,153 \mathrm{bp}$, an average length of $283 \pm 71$ and $146 \pm 24 \mathrm{bp}$, and a GC content of $54 \pm 12$ and $44 \pm 13 \%$ were uploaded to MG-RAST for BW and MDV, respectively. With this pipeline, 368,188 proteins were predicted for the BW sample and 194,410 were identified as protein features. For MDV, 6,422,118 proteins were predicted and $2,985,268$ were identified as protein features.

\section{Comparative Analysis of Microbial Diversity Among the Hot Springs}

At the domain level, the taxonomical profile generated by MG-RAST was similar in the BW and MDV samples. The highest representation of Bacterial sequences was found in both metagenomes (94.42 and 97.43\%), followed by Archaea (4.88 and 1.96\%), Eukaryota (0.66 and 0.54\%), and Viruses (0.03 and $0.06 \%$ ) (Figure 2). Proteobacteria (70.78 and $27.81 \%$ ), Deinococcus-Thermus (4.54 and 6.55\%), Firmicutes (3.91 and 
TABLE 1 | Characteristics of the metagenomic data selected for this study.

\begin{tabular}{|c|c|c|c|c|c|c|c|c|}
\hline Sample id & MG-RAST id & Hot spring & Location & $\mathrm{pH}$ & $\begin{array}{c}\text { Temperature } \\
\left({ }^{\circ} \mathrm{C}\right)\end{array}$ & $\begin{array}{c}\text { Size } \\
\text { (Mbp) }\end{array}$ & $\begin{array}{l}\text { Sequencing } \\
\text { method }\end{array}$ & References \\
\hline BW & mgm4709018.3 & As Burgas & Ourense, Spain & 7.6 & 66 & 235.68 & Illumina MiSeq & This study \\
\hline MDV & https://acortar.link/9uzzaS & Muiño da Veiga & Ourense, Spain & 7.0 & 68 & $10,408.06$ & $\begin{array}{c}\text { Illumina Hi-seq } \\
1500\end{array}$ & Unpublished \\
\hline Coamo & mgm4726046.3 & Coamo & $\begin{array}{l}\text { Coamo, Puerto } \\
\text { Rico }\end{array}$ & 8.2 & 47 & 33.10 & Illumina MiSeq & $\begin{array}{c}\text { Padilla-Del Valle } \\
\text { et al., } 2017\end{array}$ \\
\hline AT-4 & mgm4555635.3 & Atri & Odisha, India & 7.4 & 58 & 22.6 & $\begin{array}{c}\text { Roche } 454 \\
\text { GS-FLX }\end{array}$ & $\begin{array}{l}\text { Badhai et al., } \\
2015\end{array}$ \\
\hline $\mathrm{HT}-1$ & mgm4555636.3 & Athamallik & & 7.4 & 56 & 11.96 & & \\
\hline TB-3 & mgm4555637.3 & Tarabalo & & 7.3 & 57 & 22.79 & & \\
\hline TP-2 & mgm4555638.3 & Taptapani & & 7.2 & 42 & 13.81 & & \\
\hline Coquito & mgm4449206.3 & El Coquito & $\begin{array}{l}\text { Los Nevados, } \\
\text { Colombia }\end{array}$ & 2.7 & 29 & 53 & $\begin{array}{c}\text { Roche } 454 \\
\text { GS-FLX Titanium }\end{array}$ & $\begin{array}{c}\text { Jiménez et al., } \\
2012\end{array}$ \\
\hline
\end{tabular}
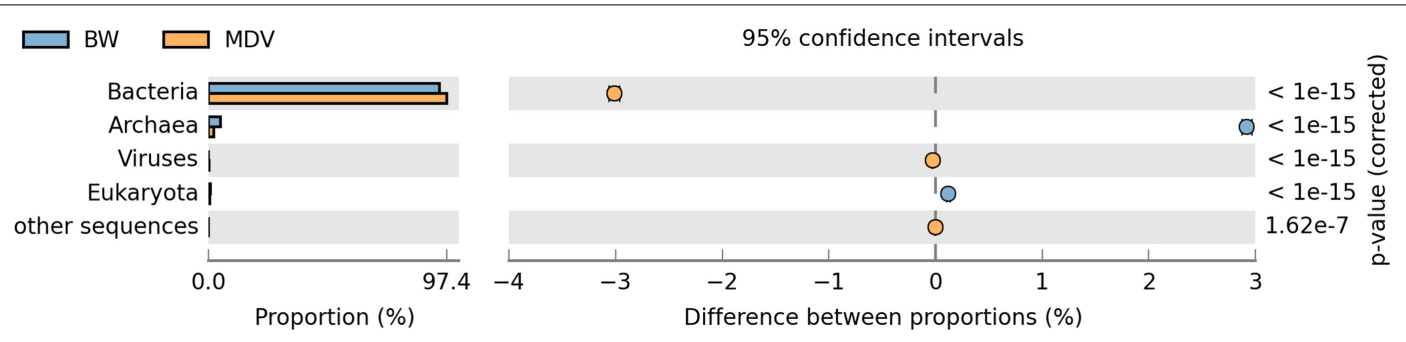

FIGURE 2 | Comparative taxonomic profile of BW and MDV at domain level.

7.89\%), Nitrospirae (0.75 and 9.22\%), and Aquificae (10.46 and $36.54 \%$ ) were the more abundant phyla in the two samples (Figure 3). However, significant differences were found between both metagenomes, as Proteobacteria were predominant in BW while Aquificae, Firmicutes, and Nitrospirae were significantly more abundant in MDV. Classes Betaproteobacteria (42.8 and 9.88\%) and Gammaproteobacteria (10.43 and 4.94\%) were overrepresented in BW, in contrast with the prevalence of Aquificae (11.07 and 35.60\%), Nitrospira (0.68 and 8.99\%), and Deltaproteobacteria (3.43 and 6.84\%) in MDV (Figure 4). A detailed list of the most abundant families found in both metagenomes can be found in Table 2 .

Proteobacteria, Deinococcus-Thermus, Aquificae, and Firmicutes were also among the most abundant phyla found in the water of the Lobios hot spring $\left(76^{\circ} \mathrm{C}, \mathrm{pH} 8.2\right)$ located at 56.36 and $56.94 \mathrm{~km}$ in a straight line from As Burgas and Muiño da Veiga hot springs, respectively, in Ourense (Galicia) (López-López et al., 2015), and are frequently found in hot springs with different $\mathrm{pH}$ and temperatures (Huang et al., 2013; Chan et al., 2015; Paul et al., 2016).

The high relative abundance of phyla Proteobacteria and Firmicutes in the studied metagenomes is consistent with the results reported for other neutral springs, with different combinations of extreme environmental conditions, where these phyla were abundantly found (Filippidou et al., 2016; Chan et al., 2017). Nevertheless, the higher relative abundance of Firmicutes in MDV sample could be related to the temperature, similar to the results found in Bakreshwar (India) in which the hot spring with higher temperature showed more abundance of this phylum
(Chaudhuri et al., 2017). A positive correlation between the abundance of phylum Firmicutes and temperature was also found in the hot springs of the Tibetan Plateau (Zhang et al., 2018).

Compared to BW, MDV water showed a higher abundance of phylum Nitrospirae (0.75 and 9.2\%). Phylum Nitrospirae is composed mainly of aerobic chemolithotrophs, including microorganisms able to perform nitrification and sulfatereducing bacteria (Garrity et al., 2001). Within phylum Nitrospirae, most species of the genus Thermodesulfovibrio have been isolated from thermal springs (Henry et al., 1994; Sonne-Hansen and Ahring, 1999; Haouari et al., 2008) and are characterized as obligately anaerobic thermophilic bacteria able to reduce sulfate and other sulfur compounds (Matsuura et al., 2016). Thermodesulfovibrio is the second most abundant genus in MDV while it is not abundant in BW (Table 3). This finding could be related to the relatively higher sulfate concentration of this hot spring compared to BW (López et al., 2019; Table 4). Thermodesulfovibrio was also abundantly found in several hot springs from Odisha (India), especially in AT-4 hot spring (Badhai et al., 2015) and in Borong hot spring (Najar et al., 2018).

With $19.27 \%$ of sequences assigned, Sulfurihydrogenibium (phylum Aquificae) is the predominant genus in MDV (Table 3). Bacteria belonging to this genus are neutrophilic and thermophilic, microaerobic or facultatively anaerobic, chemolithoautotrophic, or facultatively heterotrophic microorganisms (O'Neill et al., 2008). Sulfurihydrogenibium is also among the 14 most abundant genera found in BW, and this finding is consistent with previous reports, as this genus has been frequently found to be the most prevalent in circumneutral 


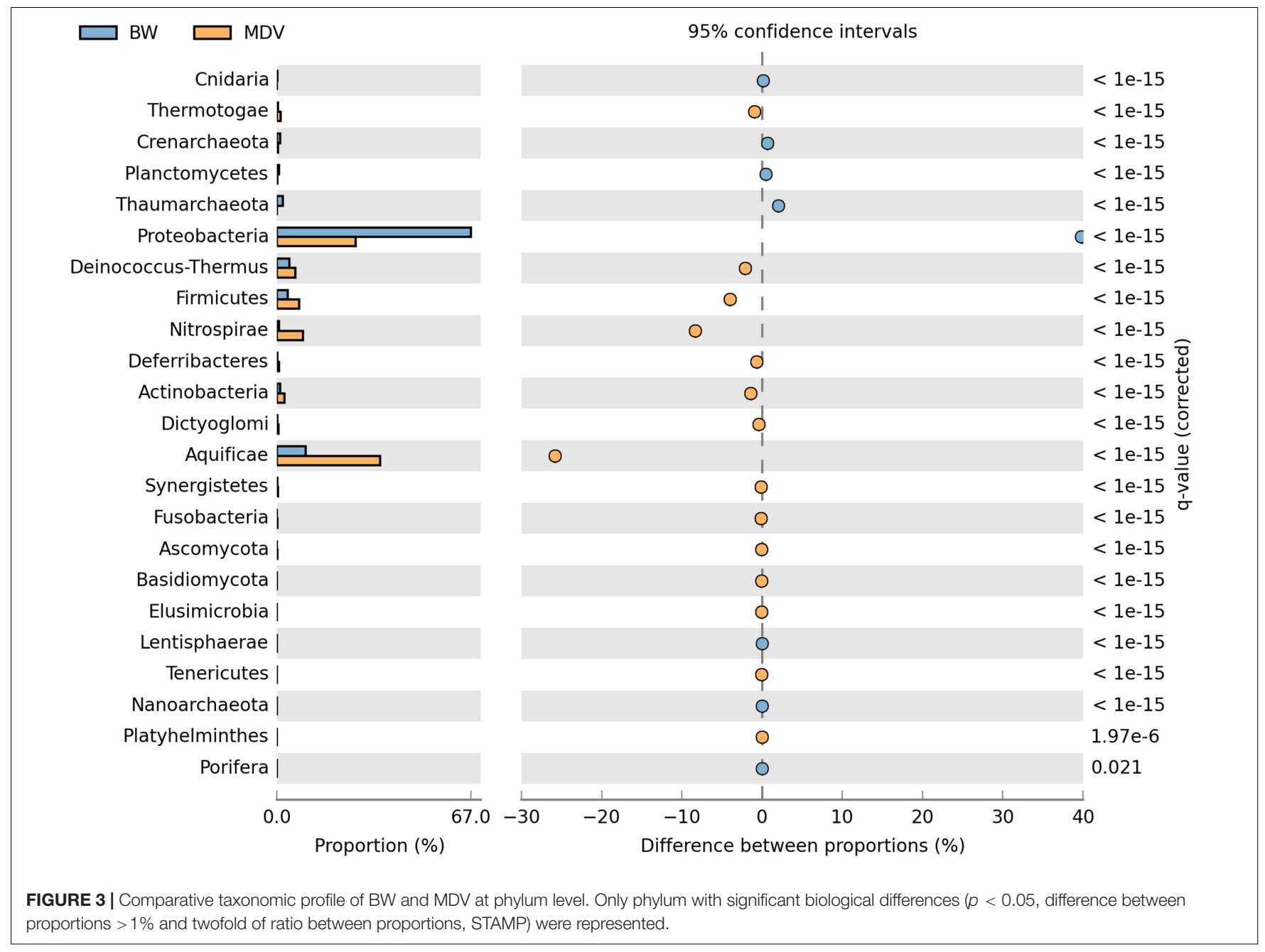

hot springs with temperatures below $75^{\circ} \mathrm{C}$ (O’Neill et al., 2008). For example, in Kamchatka hot springs, it was found that lithoautotrophic bacteria from the genus Sulfurihydrogenibium were the most abundant in those springs with near-neutral $\mathrm{pH}$ (Merkel et al., 2017). Similar results were found in the analysis of six geothermal springs from Yellowstone National Park, in which Sulfurihydrogenibium sp. dominated in neutral sulfide-rich areas (Takacs-Vesbach et al., 2013).

On the contrary, dominance in BW is more distributed among different genera (Table 3). Acidovorax (phylum Proteobacteria), Thermus (phylum Deinococcus-Thermus), Thiobacillus (phylum Proteobacteria), and Hydrogenobacter (phylum Aquificae) are the most abundant genera in this ecosystem. Acidovorax members are aerobic and chemoorganotrophic, using oxygen as the terminal electron acceptor, or in some species using the heterotrophic denitrification of nitrate (Heylen et al., 2008). Although first described as mesophilic species, several studies across the world have now linked some Acidovorax species to moderate (Padilla-Del Valle et al., 2017; Saxena et al., 2017) to high temperature hot springs (Kozubal et al., 2012; Selvarajan et al., 2018), particularly to acid-sulfate springs or iron-rich springs.
Thermus species are generally thermophilic heterotrophs able to grow using different organic sources, while several can grow mixotrophically with inorganic electron donors (thiosulfate and elemental sulfur) for respiration (Skirnisdottir et al., 2001; Bjornsdottir et al., 2009; Murugapiran et al., 2013). Although most of them are aerobic bacteria, some members of this genus are facultative anaerobic, using $\mathrm{NO}^{3-}, \mathrm{Fe}^{3+}$, or $\mathrm{S}^{0}$ as terminal electron acceptors (Alvarez et al., 2014). Its respiratory flexibility suggests an important role of the genus Thermus in sulfur, metal, and nitrogen biochemical cycles in terrestrial geothermal springs (Zhou et al., 2020). At 9.66\%, Thermus sp. is also abundant in MDV water. This finding agrees with the features described for this genus, with an optimum $\mathrm{pH}$ of 7.0-8.5 and an optimum temperature of $65-75^{\circ} \mathrm{C}$ (Massello et al., 2020); thus, Thermus sp. has been commonly found to be abundant in circumneutral thermal springs with temperatures between 60 and $80^{\circ} \mathrm{C}$ worldwide (Chan et al., 2017; Kaushal et al., 2018; Power et al., 2018).

The dominance of two heterotrophic genera such as Acidovorax and Thermus in BW metagenome might be related to the great variety of naturally occurring heteroatom-containing organic compounds reported in As Burgas water, mainly $\mathrm{N}$ - and 


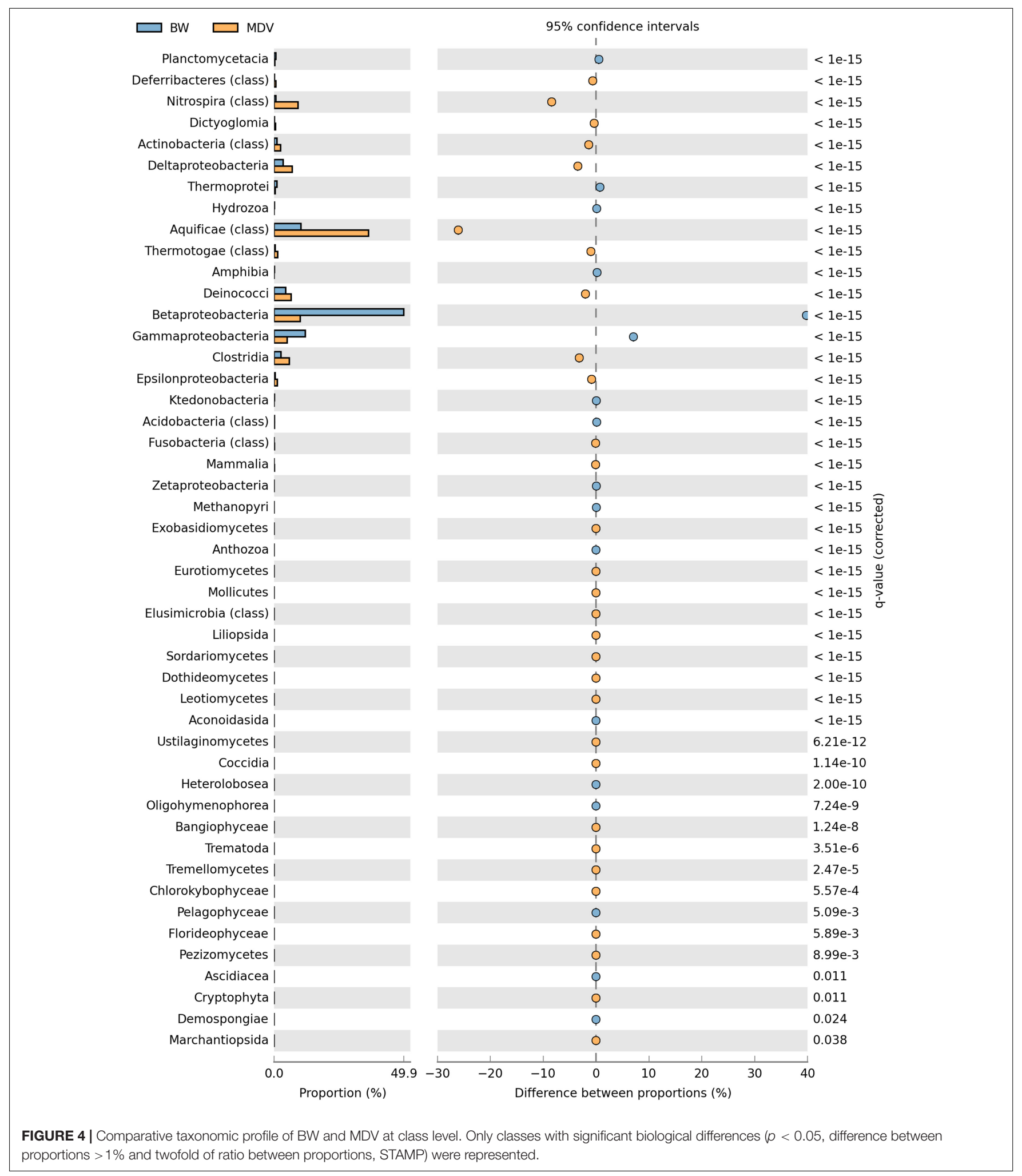

O-containing compounds, some of them with aromatic ring(s) (González-Barreiro et al., 2009).

Hydrogenobacter sp., mainly constituted by chemolithoautotrophic hydrogen- and sulfur-oxidizing bacteria that use the reductive tricarboxylic acid cycle to fix $\mathrm{CO}_{2}$ (Aoshima et al., 2004; Sano et al., 2010), is the fourth most abundant genus in BW and MDV (Table 3). These results point to the members of genera Hydrogenobacter and 
TABLE 2 | List and percentages of the four most abundant families within phyla Proteobacteria, Firmicutes, and Aquificae found in BW and MDV metagenomes.

\begin{tabular}{|c|c|c|c|c|c|}
\hline & Phylum & Class & Order & Family & $\%$ \\
\hline \multirow[t]{10}{*}{ BW } & Proteobacteria & Betaproteobacteria & Burkholderiales & Comamonadaceae & 18.09 \\
\hline & & & & Burkholderiaceae & 5.13 \\
\hline & & & Rhodocyclales & Rhodocyclaceae & 4.32 \\
\hline & & & Hydrogenophilales & Hydrogenophilaceae & 4.12 \\
\hline & Firmicutes & Clostridia & Thermoanaerobacterales & Thermoanaerobacteraceae & 0.76 \\
\hline & & & Clostridiales & Peptococcaceae & 0.54 \\
\hline & & & Clostridiales & Clostridiaceae & 0.52 \\
\hline & & Bacilli & Bacillales & Bacillaceae & 0.72 \\
\hline & Aquificae & Aquificae & Aquificales & Aquificaceae & 10.37 \\
\hline & & & & Hydrogenothermaceae & 1.34 \\
\hline \multirow[t]{10}{*}{ MDV } & Proteobacteria & Betaproteobacteria & Burkholderiales & Comamonadaceae & 3.65 \\
\hline & & & & unclassified (derived from Burkholderiales) & 1.59 \\
\hline & & & & Burkholderiaceae & 1.51 \\
\hline & & Deltaproteobacteria & Desulfuromonadales & Geobacteraceae & 2.39 \\
\hline & Firmicutes & Clostridia & Thermoanaerobacterales & Thermoanaerobacteraceae & 1.46 \\
\hline & & & Clostridiales & Clostridiaceae & 1.28 \\
\hline & & & & Peptococcaceae & 1.03 \\
\hline & & & Thermoanaerobacterales & Thermoanaerobacterales Family III. Incertae Sedis & 0.97 \\
\hline & Aquificae & Aquificae & Aquificales & Aquificaceae & 16.24 \\
\hline & & & & Hydrogenothermaceae & 20.30 \\
\hline
\end{tabular}

Sulfurihydrogenibium as mainly responsible for carbon fixation in both ecosystems. The abundance of Hydrogenobacter sp. in $\mathrm{BW}$ and MDV could be attributed to $\mathrm{pH}$, as this genus has been described as neutrophilic (Bonjour and Aragno, 1986) and has been predominantly found in neutral geothermal springs in which genus Thermus is frequently present (Massello et al., 2020). Abundance and co-occurrence of Thermus and Hydrogenobacter were previously reported for other hot springs, suggesting a possible metabolic association between both genera

TABLE 3 | List of the 14 most abundant genera in BW and MDV metagenomes.

\begin{tabular}{|c|c|c|c|}
\hline \multicolumn{2}{|l|}{ BW } & \multicolumn{2}{|l|}{ MDV } \\
\hline & $\%$ Sequences & & $\%$ Sequences \\
\hline Acidovorax & 6.89 & Sulfurihydrogenibium & 19.27 \\
\hline Thermus & 4.50 & Thermodesulfovibrio & 8.78 \\
\hline Thiobacillus & 3.89 & Aquifex & 6.60 \\
\hline Hydrogenobacter & 3.58 & Hydrogenobacter & 4.92 \\
\hline Aquifex & 3.56 & Thermus & 4.63 \\
\hline Polaromonas & 3.41 & Thermocrinis & 2.33 \\
\hline Burkholderia & 2.39 & Geobacter & 2.33 \\
\hline Nitrosopumilus & 2.26 & Acidovorax & 1.34 \\
\hline Albidiferax & 1.67 & Meiothermus & 1.23 \\
\hline Thermocrinis & 1.59 & Hydrogenobaculum & 1.15 \\
\hline Nitrosomonas & 1.54 & Clostridium & 1.07 \\
\hline Methylibium & 1.24 & Thiomonas & 0.90 \\
\hline Verminephrobacter & 1.22 & Hydrogenivirga & 0.83 \\
\hline Cupriavidus & 1.20 & Caldicellulosiruptor & 0.78 \\
\hline
\end{tabular}

Genera abundantly found in both metagenomes are highlighted in bold. Percentages were generated by MG-RAST using data from the M5NR database.
(Tomova et al., 2010; López-López et al., 2015; Ghilamicael et al., 2017; Bai and Peng, 2019).

Among the phylum Proteobacteria, members of the genus Thiobacillus are characterized by their diversity of metabolism, with a predominance of chemolitoautotrophy (Lavrentyeva et al., 2018). This genus includes sulfur-oxidizing species able to use elemental sulfur, sulfide, and thiosulfate as electron donors, such as Thiobacillus ferrooxidans and T. thiooxidans. Some species can use $\mathrm{NO}^{3-}$ as terminal electron acceptor like Thiobacillus denitrificans (Kumar et al., 2018); moreover, T. ferrooxidans has been described as potential nitrogen-fixing bacteria (Mackintosh, 1978; Rawlings and Kusano, 1994). Genus Thiobacillus is present with a $3.89 \%$ in BW, while it is not among the most abundant genera found in MDV. This genus was also detected in high abundance in Yumthang hot springs (India) (Panda et al., 2016), Shi-Huang-Ping acidic hot spring (Taiwan) (Lin et al., 2015), and Tsenkher Spring (Lavrentyeva et al., 2018).

Ammonia-oxidizing archaea (AOA) from the genus Nitrosopumilus (phylum Thaumarchaeota) were abundantly found in BW, while it is not among the 14 most abundant genera in MDV (Table 3). Several studies reported that Archaea rather than Bacteria are the main microorganisms driving ammonia oxidation in high-temperature hot springs environments (Chen et al., 2016). Although the ammonia concentration is considered to be an important factor influencing the community structure of ammonia oxidizers (Li et al., 2011; Hugoni et al., 2013; Chen et al., 2016) the dissimilarities in Nitrosopumilus abundance between both metagenomes could not be attributed to the differences in the ammonia concentration between BW and MDV waters (Table 4) as AOA have been reported to be able to grow with very low ammonia concentrations (Hatzenpichler, 2012).

When compared to the other studied hot springs, at the domain level, there is a predominance of Bacterial sequences 
TABLE 4 | Main physicochemical parameters of As Burgas and Muiño Da Veiga waters.

\begin{tabular}{|c|c|c|c|c|c|c|c|c|c|c|c|c|}
\hline & $T\left({ }^{\circ} \mathrm{C}\right)$ & $C(\mathrm{uS} / \mathrm{cm})$ & $\mathrm{pH}$ & $\mathrm{Na}^{+}$ & $\mathbf{K}^{+}$ & $\mathrm{Ca}^{2+}$ & $\mathrm{CO}_{3} \mathrm{H}^{-}$ & $\mathrm{NH}_{4}{ }^{+}$ & $\mathbf{S}$ & $\mathrm{SO}_{4}{ }^{2-}$ & $\mathrm{NO}_{2}^{-}$ & $\mathrm{NO}_{3}{ }^{-}$ \\
\hline Muiño Da Veiga & 68 & 406 & 7 & 103 & 4 & 2 & 246 & 0.58 & nd & 9 & 0.1 & 0.5 \\
\hline As Burgas & 66.3 & 960 & 7.56 & 102 & 8.2 & 11 & 0.69 & 0.94 & 0.02 & 3 & nd & 0.3 \\
\hline
\end{tabular}

Concentrations are reflected as $\mathrm{mg} \mathrm{ml}^{-1}$.

Except for $\mathrm{pH}$ and temperature, all data were extracted from Delgado-Outeiriño et al. (2009) analyses.

followed by Archaea in the eight samples, except for El Coquito and Coamo, in which eukaryotic sequences and viruses are more abundant than archaeal sequences, respectively (Figure 5). The high abundance of Eukaryota in El Coquito metagenome might be related to its relatively low temperature $\left(29^{\circ} \mathrm{C}\right)$ compared to the others. At this temperature, eukaryotic micro-algae can proliferate (Varshney et al., 2015) as important primary producers of the ecosystem taking advantage of the solar energy at the surface.

The high abundance of bacterial sequences in all the studied metagenomes, with temperatures ranging from 29 to $68^{\circ} \mathrm{C}$, is comparable to other previously analyzed hot springs such as Lobios in Ourense (López-López et al., 2015), Comano in Italy (Pedron et al., 2019), Ma'in and Afra hot springs in Jordania (Hussein et al., 2017), or the hot springs from Bakreshwar (India) (Chaudhuri et al., 2017).

Focusing on the Bacteria domain, at the phylum level, there is a clear predominance of Proteobacteria in BW, Coamo, HT-1, TB-3, TP-2, and Coquito metagenomes (Figure 6). The 95.03\% of Proteobacterial sequences in Coamo hot spring metagenome is the highest of the eight metagenomes and could be a product of the library construction, as in the pCC1FOS system utilized by Padilla-Del Valle et al. (2017), Escherichia coli Epi300- $\mathrm{T}^{R}\left[\mathrm{~F}^{-}\right.$mcrA $\Delta\left(\mathrm{mrr}^{-}\right.$hs $d \mathrm{RMS}^{-}$mcrBC) $\varphi 80 \mathrm{~d} l a c Z \Delta \mathrm{M} 15 \Delta$ lacX74 recA1 endA1 araD139 $\Delta($ ara, leu $) 7697$ galU galK $\lambda^{-} \operatorname{rpsL}$ nupG $\operatorname{trf} \mathrm{A}$ ton $\left.\mathrm{A} d h f r\right]$ was used as host, and the taxonomic assignment in MG-RAST shows that the

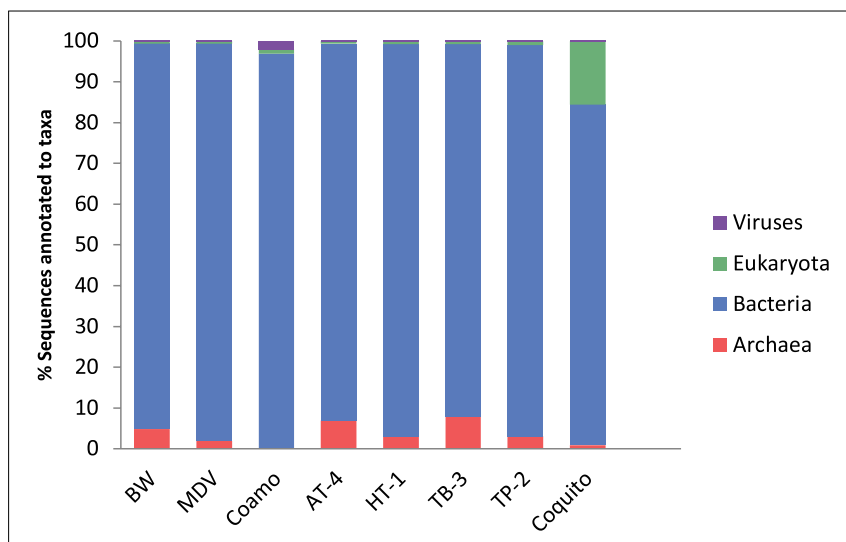

FIGURE 5 | Comparative microbial diversity at different hot springs at domain level. Chart was generated using microbial abundance data. Each chart represents the percentage of abundance of each microbial group in a specific spring. Abundance values are generated from normalized data retrieved from MG-RAST. more abundant sequences in Coamo thermal spring at the genus level are annotated as Escherichia (26\%), a genus that is not frequently found as predominant in this kind of thermal environments. Moreover, although the study mentions the removal of vector pCC1FOS sequences, there is no evidence in the section "Materials and Methods" of the extraction of E. coli host sequences, which is an important step, as was reflected in other taxonomical studies that generated their sequences from a metagenomic library constructed in the pCC1FOS system (López-López et al., 2015; Rabelo-Fernandez et al., 2018; Soriano et al., 2018). On the contrary, this result might be a real reflection of Coamo microbial population, since this is a moderate temperature hot spring $\left(47^{\circ} \mathrm{C}\right)$ and it has been demonstrated that several $E$. coli strains are thermotolerant bacteria that can evolve to grow at higher temperatures (Rudolph et al., 2010). Furthermore, E. coli has been detected in a thermal spring in Unkeswar (India) (Rekadwad and Khobragade, 2016) and in five hot springs of Eritrea (Ghilamicael et al., 2018). Additionally, in Coamo thermal spring, the genus Microvirus, constituted by single-stranded DNA viruses that infect Enterobacteria such as Escherichia (Krupovic and Forterre, 2011), is also abundantly found after taxonomic assignment by MG-RAST.

The high abundance of proteobacterial sequences in six of the eight studied metagenomes might be related to temperature, according to previous studies that have reported the predominance of phylum Proteobacteria in geographically distant moderate-temperature thermal springs such as Siloam in South Africa (Tekere et al., 2011), Attri and Yumthang in India

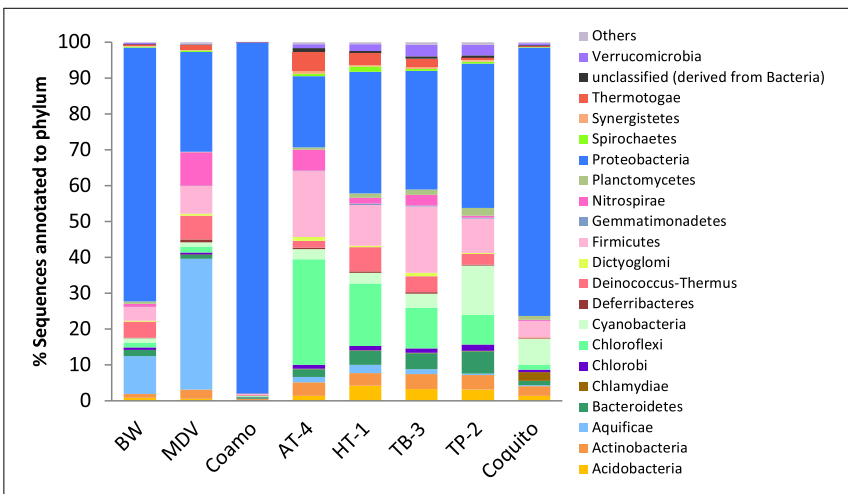

FIGURE 6 | Comparative microbial diversity within Bacteria domain at phylum level. Others include those phyla with less than $0.3 \%$ sequences annotated in the eight metagenomes: Candidatus Poribacteria, Chrysiogenetes, Elusimicrobia, Fibrobacteres, Lentisphaerae, Tenericutes, and Fusobacteria. 
(Panda et al., 2016; Tripathy et al., 2016), Ayer Hangat, Sungai Serai, and Dusun Tua in Malaysia (Chan et al., 2017), or Tatta Pani in Pakistan (Amin et al., 2017). Guo et al. (2020) suggested temperature as the main factor shaping the microbial community of 16 hot springs from the Tibetan Plateau as they found that hot springs with lower temperature $\left(<45^{\circ} \mathrm{C}\right)$ showed a dominance of Proteobacteria and Nitrospirae, while in moderate- $\left(55-70^{\circ} \mathrm{C}\right)$ to high-temperature $\left(>70^{\circ} \mathrm{C}\right)$ geothermal springs, Aquificae, Deinococcus-Thermus, Thermodesulfobacteria, Thermotogae, and Cyanobacteria were the most abundant phyla. In agreement with Guo et al. (2020), from the eight hot springs studied here, proteobacterial sequences were the most abundant in those with lower temperatures (Coquito, Coamo, and TP-2) but, on the contrary, phylum Nitrospirae was not abundant. Moreover, the dominant phyla described for the moderate- to high-temperature Tibetan Plateau hot springs are relatively more abundant in the moderate- to high-temperature hot springs studied here, but Proteobacteria phylum is also abundant.

On the other hand, in all the Indian samples (AT-4, TP2, HB-1, and TB-3), Firmicutes is a very abundant phylum with a percentage ranging from 9.7 to $18.6 \%$, as reflected in Figure 5. Based on its abundance, Firmicutes is considered a signature phylum for circumneutral hot springs in several studies (Chan et al., 2017). Nevertheless, high abundance of Firmicutes has been reported in other Indian hot springs with alkaline $\mathrm{pH}$ and temperatures between 42 and $65^{\circ} \mathrm{C}$ such as Tuwa, Lasundra, Tulsi Shyam, and Bakreshwar (Ghelani et al., 2015; Mangrola et al., 2015a,b; Chaudhuri et al., 2017), suggesting that Firmicutes abundance in these samples might be due to other parameters related with the geographical proximity. Also, in all the Indian springs studied here, there is a clear abundance of Chloroflexi when compared with the rest of the samples.

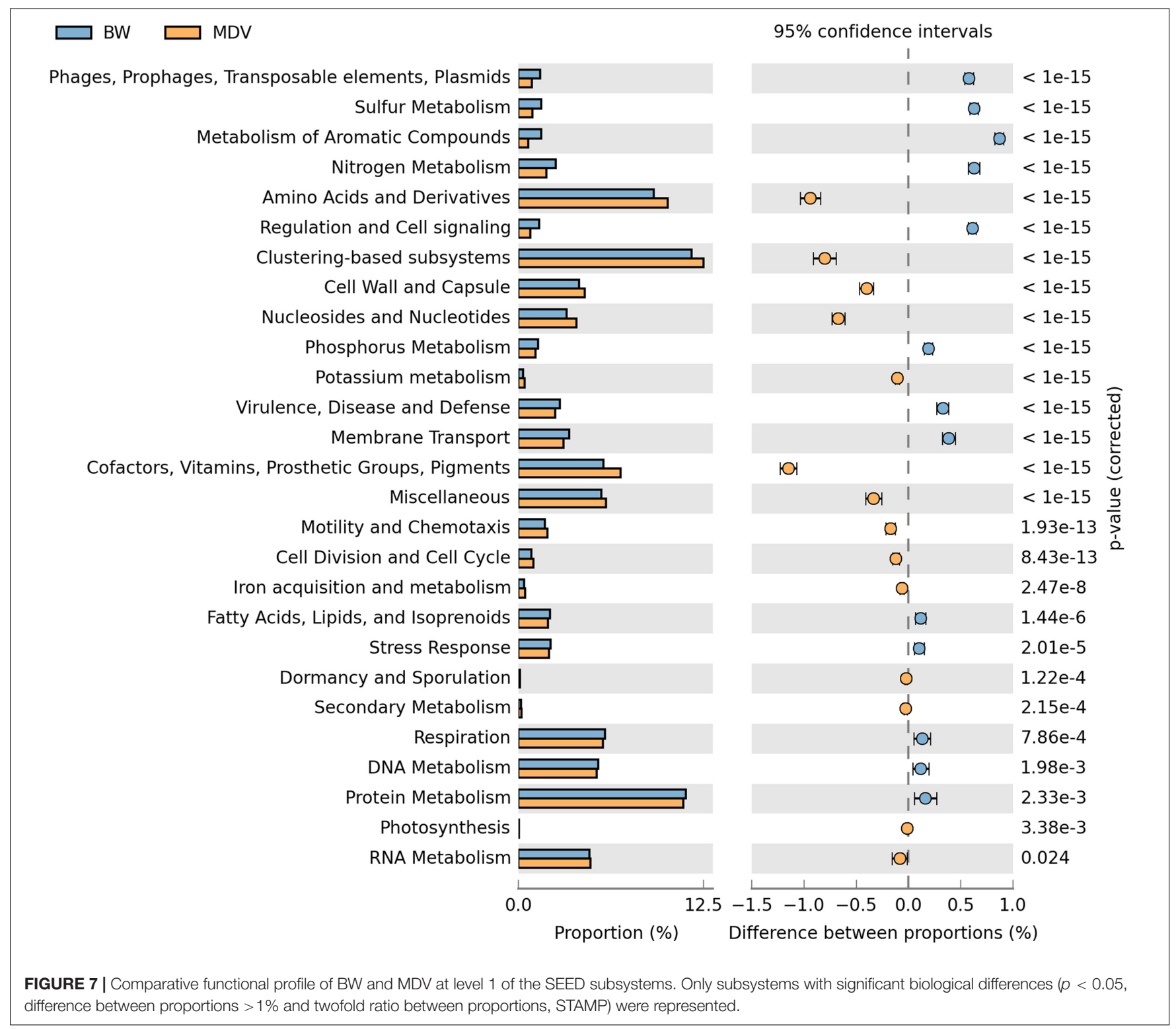


TABLE 5 | Percentages of sequences assigned to each functional category in sulfur metabolism, nitrogen metabolism, and $\mathrm{CO}_{2}$ fixation at level 3 in $\mathrm{BW}$ and MDV metagenomes.

\begin{tabular}{|c|c|c|c|}
\hline & & \multicolumn{2}{|c|}{$\%$ Sequences } \\
\hline & & BW & MDV \\
\hline \multirow{12}{*}{$\begin{array}{l}\text { Sulfur } \\
\text { Metabolism }\end{array}$} & Inorganic Sulfur Assimilation & 0.374 & 0.212 \\
\hline & $\begin{array}{l}\text { Galactosylceramide and Sulfatide } \\
\text { metabolism }\end{array}$ & 0.002 & 0.009 \\
\hline & $\begin{array}{l}\text { Release of Dimethyl Sulfide from } \\
\text { Dimethylsulfoniopropionate }\end{array}$ & 0 & $8.03 e^{-05}$ \\
\hline & $\begin{array}{l}\text { Sulfate reduction-associated } \\
\text { complexes }\end{array}$ & 0.156 & 0.164 \\
\hline & Sulfur oxidation & 0.731 & 0.364 \\
\hline & Thioredoxin-disulfide reductase & 0.100 & 0.112 \\
\hline & Alkanesulfonate assimilation & 0.023 & 0.033 \\
\hline & Alkanesulfonates Utilization & 0.002 & 0.004 \\
\hline & DMSP breakdown & $2.742 e^{-04}$ & $2.892 e^{-04}$ \\
\hline & L-Cystine Uptake and Metabolism & 0.003 & 0.007 \\
\hline & Taurine Utilization & 0.003 & 0.004 \\
\hline & $\begin{array}{l}\text { Utilization of glutathione as a sulfur } \\
\text { source }\end{array}$ & 0.018 & 0.016 \\
\hline \multirow{11}{*}{$\begin{array}{l}\text { Nitrogen } \\
\text { Metabolism }\end{array}$} & Allantoin Utilization & 0.013 & 0.013 \\
\hline & $\begin{array}{l}\text { Amidase clustered with urea and } \\
\text { nitrile hydratase functions }\end{array}$ & 0 & $2.580 e^{-04}$ \\
\hline & Ammonia assimilation & 0.625 & 0.586 \\
\hline & Cyanate hydrolysis & 0.012 & 0.011 \\
\hline & Denitrification & 0.190 & 0.218 \\
\hline & Dissimilatory nitrite reductase & 0.153 & 0.132 \\
\hline & Nitrate and nitrite ammonification & 1.144 & 0.578 \\
\hline & Nitric oxide synthase & 0.011 & 0.019 \\
\hline & Nitrilase & 0 & $6.427 e^{-05}$ \\
\hline & Nitrogen fixation & 0.164 & 0.271 \\
\hline & Nitrosative stress & 0.009 & 0.071 \\
\hline \multirow[t]{5}{*}{$\mathrm{CO}_{2}$ fixation } & TCA cycle & 0.487 & 0.311 \\
\hline & Calvin-Benson cycle & 0.645 & 0.398 \\
\hline & Carboxysome & 0.065 & 0.049 \\
\hline & $\mathrm{CO}_{2}$ uptake, carboxysome & 0.295 & 0.163 \\
\hline & $\begin{array}{l}\text { Photorespiration (oxidative C2 } \\
\text { cycle) }\end{array}$ & 0.266 & 0.297 \\
\hline
\end{tabular}

Bacteria from phylum Chloroflexi show a great variation in their metabolisms, with autotrophic, heterotrophic, and mixotrophic members (Bennett et al., 2020). The presence of Chloroflexi in the four Indian hot springs investigated by Badhai et al. (2015) and selected for this study is clearly correlated with temperature and with the distribution of phylum Cyanobacteria, as the abundance of phylum Chloroflexi increases with temperature while the abundance of cyanobacterial sequences decreases (Figure 6). Similarly, Wang et al. (2013) found that in Tibetan hot springs with moderate temperatures, abundances of phyla Cyanobacteria and Chloroflexi were negatively correlated. Another recent study also reported a decrease of the phototrophic Cyanobacteria with increasing temperature and maintenance of phototrophic Chloroflexi populations (Bennett et al., 2020).
Coquito and TP-2 are the hot springs with higher representation of Cyanobacteria in their microbial communities with 7.3 and $13.1 \%$ of cyanobacterial sequences, respectively. This finding agrees with their lower temperature $\left(29^{\circ} \mathrm{C}\right.$ in Coquito and $42^{\circ} \mathrm{C}$ in TP-2) that favors the survival of bacteria belonging to this phylum. Other studies have reported higher abundance of Cyanobacteria in lower-temperature hot springs (Sompong et al., 2005; Wang et al., 2013; Chan et al., 2017; Singh et al., 2018).

The presence of phylum Aquificae is higher in the two thermal springs from Ourense (Spain) with abundances of $10.43 \%$ in BW and $36.46 \%$ in MDV, in which it is the dominant phylum. This result might be related to their higher temperature, as some studies reported that the presence of Aquificae is positively correlated with temperature (Wang et al., 2013). Guo et al. (2020) also described higher abundance of phylum Aquificae in moderate- to high-temperature hot springs of the Tibetan Plateau than in those with lower temperatures. Other thermal springs with dominance of phylum Aquificae are Malangto $\left(75.8^{\circ} \mathrm{C}\right.$, $\mathrm{pH}$ 5.08) and Balasbas $\left(60.5^{\circ} \mathrm{C}, \mathrm{pH} 5.20\right)$ in the Philippines (Huang et al., 2013).

Actinobacteria are present in all the studied metagenomes with percentages between $4.2 \%$ (TB-3) and $0.5 \%$ (Coamo). This phylum, first considered as characteristic from soil, nowadays has been reported as ubiquitous in hot springs as it has been found in several hot springs with very diverse $\mathrm{pH}$ and temperatures (Jiang et al., 2012; Valverde et al., 2012; Liu et al., 2016).

Phylum Deinococcus-Thermus is present in all the samples except for Coamo and Coquito metagenomes in which this phylum is almost absent. The absence of this phylum in Coquito and Coamo hot springs is related to their low temperatures, as all the members of the order Thermales require temperatures higher than $60^{\circ} \mathrm{C}$ to grow (Banerjee et al., 2014).

\section{Comparative Analysis of Functional Features Among the Hot Springs}

The functional profile generated with MG-RAST showed significant differences in proportion for subsystems at level 1 between $\mathrm{BW}$ and MDV metagenomes (considering $p<0.05$ and differences of at least $1 \%$ and a twofold ratio between proportions) (Figure 7). Nevertheless, the clustering-based subsystems (11.68 and $12.48 \%$ ), protein metabolism (11.29 and $11.12 \%$ ), and amino acid and derivatives (9.12 and 10.06\%) subsystems were the most abundant functional categories at level 1 in BW and MDV. The clustering-based subsystem groups protein families with functional coupling evidence but unknown function, and was also the most abundant subsystem found in the water of the Lobios hot spring in Ourense (López-López et al., 2015).

Interestingly, sulfur and nitrogen metabolism subsystems are overrepresented in BW. Focusing on these subsystems, there is a clear difference in the percentage of sequences assigned to each functional category at level 3 between both metagenomes (Table 5). In the sulfur metabolism, there is a predominance of sulfur oxidation affiliated sequences in BW with respect to MDV (Table 5). The relative abundance of sequences annotated 
TABLE 6 | Functions involved in sulfur oxidation and DNRA associated to the genera Thermus, Thiobacillus, and Sulfurihydrogenibium found in As Burgas water metagenome.

\begin{tabular}{|c|c|c|c|c|}
\hline & & \multicolumn{3}{|c|}{ Number of sequences } \\
\hline & & Thermus & Thiobacillus & Sulfurihydrogenibium \\
\hline \multirow[t]{9}{*}{ Sulfur oxidation } & SoxH protein, homolog & & 70 & 24 \\
\hline & Sulfide dehydrogenase [flavocytochrome C] flavoprotein chain precursor (EC 1.8.2.-) & 13 & & \\
\hline & Sulfite dehydrogenase cytochrome subunit SoxD & 14 & & \\
\hline & Sulfur oxidation molybdopterin C protein & 12 & & \\
\hline & Sulfur oxidation protein SoxB & 23 & 201 & 10 \\
\hline & Sulfur oxidation protein SoxX & 41 & & \\
\hline & Sulfur oxidation protein SoxY & 8 & 35 & 1 \\
\hline & Sulfur oxidation protein SoxZ & 4 & 84 & \\
\hline & sulfur oxidation protein SoxA & 23 & & \\
\hline \multirow[t]{9}{*}{ DNRA } & Nitrate ABC transporter, ATP-binding protein & & 1 & 22 \\
\hline & Nitrate ABC transporter, permease protein & & 1 & \\
\hline & Nitrate/nitrite response regulator protein & & 97 & \\
\hline & Nitrate/nitrite sensor protein (EC 2.7.3.-) & & 102 & \\
\hline & Nitrate/nitrite transporter & & 9 & \\
\hline & Respiratory nitrate reductase alpha chain (EC 1.7.99.4) & & 49 & \\
\hline & Respiratory nitrate reductase beta chain (EC 1.7.99.4) & & 53 & 1 \\
\hline & Respiratory nitrate reductase delta chain (EC 1.7.99.4) & & 32 & \\
\hline & Respiratory nitrate reductase gamma chain (EC 1.7.99.4) & & 49 & \\
\hline
\end{tabular}

as sulfur oxidation might be related to the presence of genera Thermus, Thiobacillus, Thiomonas, and Sulfurihydrogenibium in BW. Moreover, among the sequences annotated to the genera Thermus, Thiobacillus, and Sulfurihydrogenibium, reads associated to sulfur oxidation such as those coding for the SoxB and SoxY proteins were found in BW metagenome by functional annotation of the reads (Table 6).

The abundance of sequences related to nitrate and nitrite ammonification in BW, also known as dissimilatory nitrate reduction to ammonium (DNRA), could be associated with the predominance of genera Thermus and Thiobacillus in this metagenome, which can use $\mathrm{NO}^{3-}$ as the final electron acceptor, producing ammonia. In fact, some Thiobacillus sequences affiliated with genes involved in this pathway have been found (Table 6). Therefore, these genera might also be responsible for the relatively higher concentration of ammonia in $\mathrm{BW}$ when compared to $\mathrm{MDV}$, stimulating the occurrence of ammonia oxidizers, such as those from the genus Nitrosopumilus, in the ecosystem.

The percentages of sequences assigned to denitrification, nitrogen fixation, and nitrosative stress functions are relatively

TABLE 7 | Reads from the genera Sulfurihydrogenibium annotated as denitrification functions in Muiño Da Veiga metagenome.

\begin{tabular}{lc}
\hline & Sulfurihydrogenibium \\
\hline Cytochrome cd1 nitrite reductase (EC:1.7.2.1) & 2464 \\
Nitrous oxide reductase maturation protein, & 273 \\
outer-membrane lipoprotein NosL & \\
Nitrous oxide reductase maturation transmembrane & 440 \\
protein NosY &
\end{tabular}

higher in MDV than in BW (Table 5). Recent studies have suggested an association between nitrogen fixation and sulfate reduction in hot springs, proposing chemolithoautotrophic sulfate-reducing bacteria as mainly responsible for nitrogen fixation (Nishihara et al., 2018b). Moreover, all the genes necessary for nitrogen fixation have been found in several Thermodesulfovibrio species (Frank et al., 2016), and members of this genus have been pointed as possible nitrogen-fixing bacteria in Nakabusa hot springs in Japan (Nishihara et al., 2018a) and Mushroom spring in Yellowstone National Park (Thiel et al., 2017), although diazotrophic growth has not been demonstrated yet in the laboratory for any Thermodesulfovibrio species. In addition, the lower ammonia concentration of MDV (Table 3) might be promoting a selective pressure for the growth of diazotrophic bacteria able to fix $\mathrm{N}_{2}$, as has been generally reported in geothermal springs (Hamilton et al., 2014).

The elevated percentage of sequences involved in denitrification annotated in MDV could be associated with the dominance of genus Sulfurihydrogenibium, since the ability to denitrify completely to $\mathrm{N}_{2}$ has been described in several Sulfurihydrogenibium species (Takai et al., 2003). Indeed, by submitting the Sulfurihydrogenibium annotated reads to the Subsystems database in the MG-RAST, our data confirmed the presence of Sulfurihydrogenibium sequences involved in denitrification, such as Cytochrome cdl nitrite reductase (EC:1.7.2.1) (Table 7).

These results suggest that the two main genera in MDV (Sulfurihydrogenibium and Thermodesulfovibrio) play an important role, not only in the sulfur cycle, but also in the nitrogen cycle. Moreover, the co-dominance of genera Sulfurihydrogenibium and Thermodesulfovibrio in MDV reveals the importance of sulfur metabolism in this hot spring and 


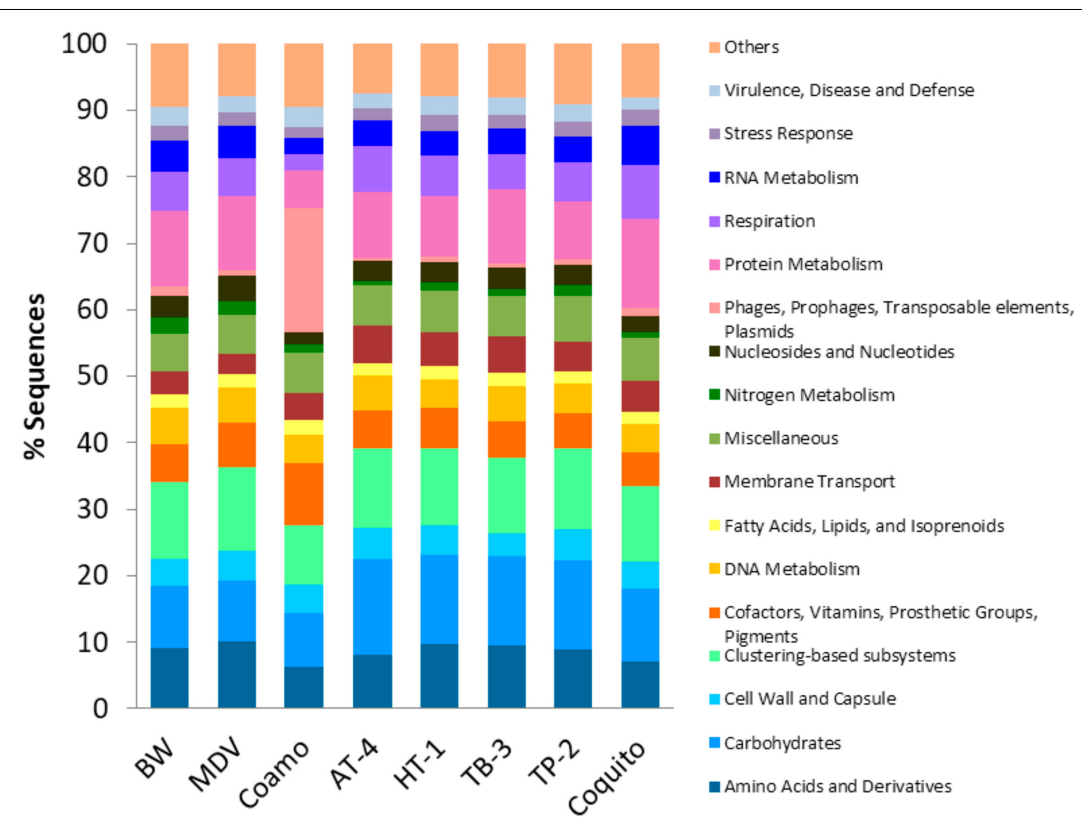

FIGURE 8 | Comparative functional diversity at level 1. Others include those subsystems with less than $2 \%$ sequences annotated in the eight metagenomes: Cell division and cell cycle, dormancy and sporulation, iron acquisition and metabolism, metabolism of aromatic compounds, motility and chemotaxis, phosphorus metabolism, photosynthesis, potassium metabolism, regulation and cell signaling, secondary metabolism, and sulfur metabolism.

suggests the existence of a sulfur cycle in MDV geothermal spring between the two dominant genera, in which Thermodesulfovibrio would be reducing sulfate to sulfide through anaerobic sulfate respiration; sulfide is then abiotically or biotically oxidized to thiosulfate (Chen and Morris, 1972) and thiosulfate is used by Sulfurihydrogenibium as electron donor, producing sulfate (Takai et al., 2003). Furthermore, Sulfurihydrogenibium can grow autotrophically using elemental sulfur as an electron donor and nitrate as a final electron acceptor, producing sulfate, liberating $\mathrm{N}_{2}$, and coupling both sulfur and nitrogen cycles.

Focusing on the carbon fixation, an abundance of sequences affiliated to the Calvin-Benson Cycle is found in BW when compared to MDV. This might be related to the significantly higher proportion of Betaproteobacteria and Gammaproteobacteria in BW hot spring (Figure 4), as the autotrophic members of these taxonomic classes use the reductive pentose phosphate (Calvin-Benson) cycle to fix carbon (Hügler and Sievert, 2011). Sequences annotated within the tricarboxylic acid (TCA) cycle can be associated with the catabolism but also with the carbon fixation via the reductive TCA cycle performed by representatives of the genera Hydrogenobacter, Thermocrinis, and Sulfurihydrogenibium, among others (Hügler et al., 2007).

In relation to the functional profile of the studied metagenomes, the relative abundance of the 23 functions assigned by subsystems at level 1 is very similar in all the metagenomes with the exception of Coamo hot spring in which a higher proportion of sequences annotated as phages, prophages, transposable elements, and plasmids was detected (Figure 8). This result was expected due to the abundance of viral sequences (Figure 5) reported in Coamo metagenome compared to the other hot springs. On the contrary, sequences related to protein metabolism and cofactors, vitamins, prosthetic groups, and pigments were significantly lower in Coamo than in the rest of metagenomes.

\section{CONCLUSION}

As the two hot springs from Ourense showed small differences in temperature and $\mathrm{pH}$, the differences in bacterial community between BW and MDV are due to the previously described differences in the geochemical composition of their waters (González-Barreiro et al., 2009). The dominance of a heterotrophic population of the genus Thermus in BW is related to the high abundance of organic compounds detected in this geothermal spring (González-Barreiro et al., 2009), while in MDV, there is a predominance of chemolithoautotrophy performed by the genus Sulfurihydrogenibium.

Taxonomic and functional analyses showed that primary production in both hot springs is mainly driven by members of the genera Sulfurihydrogenibium, Hydrogenobacter, and Thermocrinis, which are sulfur and hydrogen oxidizers that can fix carbon using the reverse tricarboxylic acid pathway (rTCA). However, the differences in the abundance of these genera between the two metagenomes suggest that genera Sulfurihydrogenibium and Hydrogenobacter are mainly responsible for carbon fixation in MDV and BW, respectively.

The higher concentration of sulfate in MDV might be behind the abundance of the genus Thermodesulfovibrio in this hot spring in which the existence of a sulfur cycle between the two dominant genera (Sulfurihydrogenibium and Thermodesulfovibrio) is taking place. 
In BW, ammonia oxidation driven by Archaea of the genus Nitrosopumilus can occur, while this genus is not abundant in MDV. On the other hand, the lower concentration of $\mathrm{NH}^{4+}$ in the MDV ecosystem could be driving a selection to nitrogen fixation, performed by members of the genus Thermodesulfovibrio, among others.

From a functional point of view, the results suggest a clear interaction between nitrogen and sulfur cycles in both metagenomes, as some members of the genera Thermodesulfovibrio, Sulfurihydrogenibium, and Thermus have been described as important players in both biogeochemical cycles and are abundantly found in BW and MDV hot springs, as well as the sequences related with metabolic pathways involved in nitrogen and sulfur cycles.

When compared to other geographically distant hot spring metagenomes, a clear effect of $\mathrm{pH}$ and temperature determining the taxonomy and function of hot springs microbial community can be detected. Phylum Cyanobacteria dominates in low-temperature hot springs, Proteobacteria is dominant in moderate-temperature hot springs, and Aquificae and Deninococcus-Thermus are more abundant in the hightemperature hot springs.

\section{DATA AVAILABILITY STATEMENT}

The datasets presented in this study can be found in online repositories. The names of the repository/repositories and accession number(s) can be found below: https://www.mg-rast.

\section{REFERENCES}

Alvarez, L., Bricio, C., Blesa, A., Hidalgo, A., and Berenguer, J. (2014). Transferable denitrification capability of Thermus thermophilus. Appl. Environ. Microbiol. 80, 19-28. doi: 10.1128/AEM.02594-13

Amin, A., Ahmed, I., Salam, N., Kim, B.-Y., Singh, D., Zhi, X.-Y., et al. (2017). Diversity and distribution of thermophilic bacteria in hot springs of Pakistan. Microb. Ecol. 74, 116-127. doi: 10.1007/s00248-017-0930-1

Aoshima, M., Ishii, M., and Igarashi, Y. (2004). A novel enzyme, citryl-CoA lyase, catalysing the second step of the citrate cleavage reaction in Hydrogenobacter thermophilus TK-6. Mol. Microbiol. 52, 763-770. doi: 10.1111/j.1365-2958.2004. 04010.x

Badhai, J., Ghosh, T. S., and Das, S. K. (2015). Taxonomic and functional characteristics of microbial communities and their correlation with physicochemical properties of four geothermal springs in Odisha, India. Front. Microbiol. 6:1166. doi: 10.3389/fmicb.2015.01166

Bai, S., and Peng, X. (2019). Distinct microbial composition and functions in an underground high-temperature hot spring at different depths. Biogeosci. Discuss. [preprint]. doi: 10.5194/bg-2019-406

Banerjee, R., Roy, A., and Mukhopadhyay, S. (2014). Genomic and proteomic signatures of radiation and thermophilic adaptation in the DeinococcusThermus genomes. Int. J. Pharm. Pharm. Sci. 6, 287-300.

Bennett, A. C., Murugapiran, S. K., and Hamilton, T. L. (2020). Temperature impacts community structure and function of phototrophic Chloroflexi and Cyanobacteria in two alkaline hot springs in Yellowstone National Park. Environ. Microbiol. Rep. 12, 503-513. doi: 10.1111/1758-2229.12863

Bjornsdottir, S. H., Petursdottir, S. K., Hreggvidsson, G. O., Skirnisdottir, S., Hjorleifsdottir, S., Arnfinnsson, J., et al. (2009). Thermus islandicus sp. nov., a mixotrophic sulfur-oxidizing bacterium isolated from the Torfajokull geothermal area. Int. J. Syst. Evol. Microbiol. 59, 2962-2966. doi: 10.1099/ijs.0. 007013-0 org, mgm4709018.3, https://www.mg-rast.org, https://acortar. link/9uzzaS.

\section{AUTHOR CONTRIBUTIONS}

M-ED did the writing, metagenomic DNA extraction, sequencing, and annotation of As Burgas water. J-JE-R did the metagenomic DNA extraction and annotation of Muiño da Veiga water. ER-B, MB, and M-IG-S supervised and reviewed the manuscript, providing comments and guidance during the work, and manuscript development. All authors contributed to the article and approved the submitted version.

\section{FUNDING}

This study received financial support from the following organizations: Xunta de Galicia (Consolidación GRC) cofinanced by FEDER (Grant Number ED431C 2020/08) and Ministerio de Ciencia, Innovación y Universidades (MICINN) (Grant Number RTI2018-099249-B-I00). The work of M-ED was supported by a FPU fellowship (Ministerio de Educación Cultura y Deporte) FPU12/05050. The metagenome sequencing of As Burgas water was performed by M-ED in the Dinsdale Lab (Department of Biology, San Diego State University), as part of a short stay financed by the Short-Term Mobility program of the FPU scholarship.

Bonjour, F., and Aragno, M. (1986). Growth of thermophilic, obligatorily chemolithoautotrophic hydrogen-oxidizing bacteria related to Hydrogenobacter with thiosulfate and elemental sulfur as electron and energy source. FEMS Microbiol. Lett. 35, 11-15. doi: 10.1111/j.1574-6968.1986. tb01490.x

Chan, C. S., Chan, K.-G., Ee, R., Hong, K.-W., Urbieta, M. S., Donati, E. R., et al. (2017). Effects of physiochemical factors on prokaryotic biodiversity in Malaysian circumneutral hot springs. Front. Microbiol. 8:1252. doi: 10.3389/ fmicb.2017.01252

Chan, C. S., Chan, K.-G., Tay, Y.-L., Chua, Y.-H., and Goh, K. M. (2015). Diversity of thermophiles in a Malaysian hot spring determined using 16S rRNA and shotgun metagenome sequencing. Front. Microbiol. 6:177. doi: 10.3389/fmicb. 2015.00177

Chaudhuri, B., Chowdhury, T., and Chattopadhyay, B. (2017). Comparative analysis of microbial diversity in two hot springs of Bakreshwar, West Bengal, India. Genomics Data 12, 122-129. doi: 10.1016/j.gdata.2017.04.001

Chen, K. Y., and Morris, J. C. (1972). Kinetics of oxidation of aqueous sulfide by O2. Environ. Sci. Technol. 6, 529-537. doi: 10.1021/es60065a008

Chen, S., Peng, X., Xu, H., and Ta, K. (2016). Nitrification of archaeal ammonia oxidizers in a high-temperature hot spring. Biogeosciences 13, 2051-2060. doi: 10.5194/bg-13-2051-2016

Chiriac, C. M., Szekeres, E., Rudi, K., Baricz, A., Hegedus, A., Dragoş, N., et al. (2017). Differences in temperature and water chemistry shape distinct diversity patterns in thermophilic microbial communities. Appl. Environ. Microbiol. 83:e01363-17. doi: 10.1128/AEM.01363-17

Deive, F. J., Álvarez, M. S., Sanromán, M. A., and Longo, M. A. (2013). North Western Spain hot springs are a source of lipolytic enzyme-producing thermophilic microorganisms. Bioprocess Biosyst. Eng. 36, 239-250. doi: 10. 1007/s00449-012-0780-7

Delgado-Outeiriño, I., Araujo-Nespereira, P., Cid-Fernández, J. A., Mejuto, J. C., Martínez-Carballo, E., and Simal-Gándara, J. (2009). Behaviour of thermal 
waters through granite rocks based on residence time and inorganic pattern. J. Hydrol. 373, 329-336. doi: 10.1016/j.jhydrol.2009.04.028

Ferrandi, E. E., Sayer, C., De Rose, S. A., Guazzelli, E., Marchesi, C., Saneei, V., et al. (2018). New thermophilic $\alpha / \beta$ class epoxide hydrolases found in metagenomes from hot environments. Front. Bioeng. Biotechnol. 6:144. doi: 10.3389/fbioe. 2018.00144

Filippidou, S., Wunderlin, T., Junier, T., Jeanneret, N., Dorador, C., Molina, V., et al. (2016). A Combination of extreme environmental conditions favor the prevalence of endospore-forming Firmicutes. Front. Microbiol. 7:1707. doi: 10. 3389/fmicb.2016.01707

Frank, Y. A., Kadnikov, V. V., Lukina, A. P., Banks, D., Beletsky, A. V., Mardanov, A. V., et al. (2016). Characterization and genome analysis of the first facultatively alkaliphilic Thermodesulfovibrio isolated from the deep terrestrial subsurface. Front. Microbiol. 7:2000. doi: 10.3389/fmicb.2016.02000

Garrity, G. M., Holt, J. G., Spieck, E., Bock, E., Johnson, D. B., Spring, S., et al. (2001). "Phylum BVIII. Nitrospirae phy. nov," in Bergey's Manual ${ }^{\circledR}$ of Systematic Bacteriology, eds D. R. Boone, R. W. Castenholz, and G. M. Garrity (New York, NY: Springer), 451-464. doi: 10.1007/978-0-387-21609-6_25

Ghelani, A., Patel, R., Mangrola, A., and Dudhagara, P. (2015). Cultivationindependent comprehensive survey of bacterial diversity in Tulsi Shyam Hot Springs, India. Genomics Data 4, 54-56. doi: 10.1016/j.gdata.2015.03.003

Ghilamicael, A. M., Boga, H. I., Anami, S. E., Mehari, T., and Budambula, N. L. M. (2018). Potential human pathogenic bacteria in five hot springs in Eritrea revealed by next generation sequencing. PLoS One 13:e0194554. doi: 10.1371/ journal.pone.0194554

Ghilamicael, A. M., Budambula, N. L. M., Anami, S. E., Mehari, T., and Boga, H. I. (2017). Evaluation of prokaryotic diversity of five hot springs in Eritrea. BMC Microbiol. 17:203. doi: 10.1186/s12866-017-1113-4

González-Barreiro, C., Cancho-Grande, B., Araujo-Nespereira, P., Cid-Fernández, J. A., and Simal-Gándara, J. (2009). Occurrence of soluble organic compounds in thermal waters by ion trap mass detection. Chemosphere 75, 34-47. doi: 10.1016/J.CHEMOSPHERE.2008.11.067

Guo, L., Wang, G., Sheng, Y., Sun, X., Shi, Z., Xu, Q., et al. (2020). Temperature governs the distribution of hot spring microbial community in three hydrothermal fields, Eastern Tibetan Plateau Geothermal Belt, Western China. Sci. Total Environ. 720:137574. doi: 10.1016/j.scitotenv.2020.137574

Hamilton, T. L., Koonce, E., Howells, A., Havig, J. R., Jewell, T., de la Torre, J. R., et al. (2014). Competition for ammonia influences the structure of chemotrophic communities in geothermal springs. Appl. Environ. Microbiol. 80, 653-661. doi: 10.1128/AEM.02577-13

Haouari, O., Fardeau, M. L., Cayol, J. L., Fauque, G., Casiot, C., Elbaz-Poulichet, F., et al. (2008). Thermodesulfovibrio hydrogeniphilus sp. nov., a new thermophilic sulphate-reducing bacterium isolated from a Tunisian hot spring. Syst. Appl. Microbiol. 31, 38-42. doi: 10.1016/j.syapm.2007.12.002

Hatzenpichler, R. (2012). Diversity, physiology, and niche differentiation of ammonia-oxidizing archaea. Appl. Environ. Microbiol. 78, 7501-7510. doi: 10. 1128/AEM.01960-12

Henry, E. A., Devereux, R., Maki, J. S., Gilmour, C. C., Woese, C. R., Mandelco, L., et al. (1994). Characterization of a new thermophilic sulfate-reducing bacterium - Thermodesulfovibrio yellowstonii, gen. nov. and sp. nov.: its phylogenetic relationship to Thermodesulfobacterium commune and their origins deep within the bacterial domain. Arch. Microbiol. 161, 62-69. doi: 10.1007/BF00248894

Heylen, K., Lebbe, L., and de Vos, P. (2008). Acidovorax caeni sp. nov., a denitrifying species with genetically diverse isolates from activated sludge. Int. J. Syst. Evol. Microbiol. 58, 73-77. doi: 10.1099/ijs.0.65387-0

Huang, Q., Jiang, H., Briggs, B. R., Wang, S., Hou, W., Li, G., et al. (2013). Archaeal and bacterial diversity in acidic to circumneutral hot springs in the Philippines. FEMS Microbiol. Ecol. 85, 452-464. doi: 10.1111/1574-6941.12134

Hügler, M., and Sievert, S. M. (2011). Beyond the Calvin cycle: autotrophic carbon fixation in the ocean. Ann. Rev. Mar. Sci. 3, 261-289. doi: 10.1146/annurevmarine-120709-142712

Hügler, M., Huber, H., Molyneaux, S. J., Vetriani, C., and Sievert, S. M. (2007). Autotrophic $\mathrm{CO} 2$ fixation via the reductive tricarboxylic acid cycle in different lineages within the phylum Aquificae: evidence for two ways of citrate cleavage. Environ. Microbiol. 9, 81-92. doi: 10.1111/j.1462-2920.2006.01118.x

Hugoni, M., Etien, S., Bourges, A., Lepère, C., Domaizon, I., Mallet, C., et al. (2013). Dynamics of ammonia-oxidizing Archaea and Bacteria in contrasted freshwater ecosystems. Res. Microbiol. 164, 360-370. doi: 10.1016/j.resmic.2013. 01.004

Hussein, E. I., Jacob, J. H., Shakhatreh, M. A. K., Abd Al-razaq, M. A., Juhmani, A. F., and Cornelison, C. T. (2017). Exploring the microbial diversity in Jordanian hot springs by comparative metagenomic analysis. Microbiol. Open 6:e00521. doi: $10.1002 / \mathrm{mbo} 3.521$

Jiang, H., Dong, C. Z., Huang, Q., Wang, G., Fang, B., Zhang, C., et al. (2012). Actinobacterial diversity in microbial mats of five hot springs in Central and Central-Eastern Tibet, China. Geomicrobiol. J. 29, 520-527. doi: 10.1080/ 01490451.2011.590872

Jiménez, D. J., Andreote, F. D., Chaves, D., Montaña, J. S., Osorio-Forero, C., Junca, H., et al. (2012). Structural and functional insights from the metagenome of an acidic hot spring microbial planktonic community in the Colombian Andes. PLoS One 7:e52069. doi: 10.1371/journal.pone.0052069

Kaushal, G., Kumar, J., Sangwan, R. S., and Singh, S. P. (2018). Metagenomic analysis of geothermal water reservoir sites exploring carbohydrate-related thermozymes. Int. J. Biol. Macromol. 119, 882-895. doi: 10.1016/j.ijbiomac. 2018.07.196

Konhauser, K. O., Jones, B., Reysenbach, A. L., and Renaut, R. W. (2003). Hot spring sinters: keys to understanding Earth's earliest life forms. Can. J. Earth Sci. 40, 1713-1724. doi: 10.1139/e03-059

Kozubal, M. A., Macur, R. E., Jay, Z. J., Beam, J. P., Malfatti, S. A., Tringe, S. G., et al. (2012). Microbial iron cycling in acidic geothermal springs of Yellowstone National Park: integrating molecular surveys, geochemical processes, and isolation of novel Fe-active microorganisms. Front. Microbiol. 3:109. doi: 10. 3389/fmicb.2012.00109

Krupovic, M., and Forterre, P. (2011). Microviridae goes temperate: microvirusrelated Proviruses reside in the genomes of Bacteroidetes. PLoS One 6:e19893. doi: 10.1371/journal.pone.0019893

Kumar, U., Panneerselvam, P., Gupta, V. V. S. R., Manjunath, M., Priyadarshinee, P., Sahoo, A., et al. (2018). "Diversity of sulfur-oxidizing and sulfur-reducing microbes in diverse ecosystems," in Advances in Soil Microbiology: Recent Trends and Future Prospects. Microorganisms for Sustainability, Vol. 3, eds T. Adhya, B. Lal, B. Mohapatra, D. Paul, and S. Das (Singapore: Springer), 65-89. doi: 10.1007/978-981-10-6178-3_4

Lavrentyeva, E. V., Radnagurueva, A. A., Barkhutova, D. D., Belkova, N. L., Zaitseva, S. V., Namsaraev, Z. B., et al. (2018). Bacterial diversity and functional activity of microbial communities in hot springs of the Baikal Rift zone. Microbiol. Russian Fed. 87, 272-281. doi: 10.1134/S0026261718020078

Leira, M., Meijide-Failde, R., and Torres, E. (2017). Diatom communities in thermo-mineral springs of Galicia (NW Spain). Diatom Res. 32, 29-42. doi: 10.1080/0269249X.2017.1286266

Li, H., Yang, Q., Li, J., Gao, H., Li, P., and Zhou, H. (2015). The impact of temperature on microbial diversity and AOA activity in the Tengchong Geothermal Field, China. Sci. Rep. 5:17056. doi: 10.1038/srep17056

Li, J., and Liu, X. (2017). Identification and Characterization of a novel thermophilic, organic solvent sable lpase of Bacillus from a hot spring. Lipids 52, 619-627. doi: 10.1007/s11745-017-4265-y

Li, M., Cao, H., Hong, Y., and Gu, J. D. (2011). Spatial distribution and abundances of ammonia-oxidizing archaea (AOA) and ammonia-oxidizing bacteria (AOB) in mangrove sediments. Appl. Microbiol. Biotechnol. 89, 1243-1254. doi: 10. 1007/s00253-010-2929-0

Lin, K.-H., Liao, B.-Y., Chang, H.-W., Huang, S.-W., Chang, T.-Y., Yang, C.-Y., et al. (2015). Metabolic characteristics of dominant microbes and key rare species from an acidic hot spring in Taiwan revealed by metagenomics. BMC Genomics 16:1029. doi: 10.1186/s12864-015-2230-9

Liu, L., Salam, N., Jiao, J. Y., Jiang, H. C., Zhou, E. M., Yin, Y. R., et al. (2016). Diversity of culturable thermophilic Actinobacteria in hot springs in Tengchong, China and studies of their biosynthetic gene profiles. Microb. Ecol. 72, 150-162. doi: 10.1007/s00248-016-0756-2

López, D. L., Araujo, P. A., Outeiriño, I. D., Cid, J. A., and Astray, G. (2019). Geochemical signatures of the groundwaters from Ourense thermal springs, Galicia, Spain. Sustain. Water Resour. Manag. 5, 103-116. doi: 10.1007/s40899018-0239-3

López-López, O., Knapik, K., Cerdán, M. E., and González-Siso, M. I. (2015). Metagenomics of an alkaline hot spring in Galicia (Spain): microbial diversity analysis and screening for novel lipolytic enzymes. Front. Microbiol. 6:1291. doi: $10.3389 /$ fmicb. 2015.01291 
Mackintosh, M. E. (1978). Nitrogen fixation by Thiobacillus ferrooxidans. J. Gen. Microbiol. 105, 215-218. doi: 10.1099/00221287-105-2-215

Mahato, N. K., Sharma, A., Singh, Y., and Lal, R. (2019). Comparative metagenomic analyses of a high-altitude Himalayan geothermal spring revealed temperature-constrained habitat-specific microbial community and metabolic dynamics. Arch. Microbiol. 201, 377-388. doi: 10.1007/s00203-018-01616-6

Mangrola, A. V., Dudhagara, P., Koringa, P., Joshi, C. G., Parmar, M., and Patel, R. (2015a). Deciphering the microbiota of Tuwa hot spring, India using shotgun metagenomic sequencing approach. Genomics Data 4, 153-155. doi: 10.1016/j. gdata.2015.04.014

Mangrola, A. V., Dudhagara, P., Koringa, P., Joshi, C. G., and Patel, R. K. (2015b). Shotgun metagenomic sequencing based microbial diversity assessment of Lasundra hot spring, India. Genomics Data 4, 73-75. doi: 10.1016/j.gdata.2015. 03.005

Massello, F. L., Chan, C. S., Chan, K.-G., Goh, K. M., Donati, E., and Urbieta, M. S. (2020). Meta-analysis of microbial communities in hot springs: recurrent taxa and complex shaping factors beyond $\mathrm{pH}$ and temperature. Microorganisms 8:906. doi: 10.3390/microorganisms 8060906

Matsuura, N., Ohashi, A., Tourlousse, D. M., and Sekiguchi, Y. (2016). Draft genome sequence of Thermodesulfovibrio aggregans TGE-P1T, an obligately anaerobic, thermophilic, sulfate-reducing bacterium in the phylum Nitrospirae. Genome Announc. 4, 89-105. doi: 10.1128/genomeA.00089-16

Mehetre, G., Shah, M., Dastager, S. G., and Dharne, M. S. (2018). Untapped bacterial diversity and metabolic potential within Unkeshwar hot springs, India. Arch. Microbiol. 200, 753-770. doi: 10.1007/s00203-018-1484-4

Menzel, P., Gudbergsdóttir, S. R., Rike, A. G., Lin, L., Zhang, Q., Contursi, P., et al. (2015). Comparative metagenomics of eight geographically remote terrestrial hot springs. Microb. Ecol. 70, 411-424. doi: 10.1007/s00248-015-0576-9

Merkel, A. Y., Pimenov, N. V., Rusanov, I. I., Slobodkin, A. I., Slobodkina, G. B., Tarnovetckii, I. Y., et al. (2017). Microbial diversity and autotrophic activity in Kamchatka hot springs. Extremophiles 21, 307-317. doi: 10.1007/s00792-0160903-1

Meyer, F., Paarmann, D., D'Souza, M., Olson, R., Glass, E., Kubal, M., et al. (2008). The metagenomics RAST server-a public resource for the automatic phylogenetic and functional analysis of metagenomes. BMC Bioinformatics 9:386. doi: 10.1186/1471-2105-9-386

Murugapiran, S. K., Huntemann, M., Wei, C.-L., Han, J., Detter, J. C., Han, C., et al. (2013). Thermus oshimai JL-2 and T. thermophilus JL-18 genome analysis illuminates pathways for carbon, nitrogen, and sulfur cycling. Stand. Genomic Sci. 7, 449-468. doi: 10.4056/sigs.3667269

Najar, I. N., Sherpa, M. T., Das, S., Das, S., and Thakur, N. (2018). Microbial ecology of two hot springs of Sikkim: predominate population and geochemistry. Sci. Total Environ. 637-638, 730-745. doi: 10.1016/J.SCITOTENV.2018.05.037

Nishihara, A., Matsuura, K., Tank, M., McGlynn, S. E., Thiel, V., and Haruta, S. (2018b). Nitrogenase activity in thermophilic chemolithoautotrophic bacteria in the phylum Aquificae; Isolated under nitrogen-fixing conditions from Nakabusa hot springs. Microbes Environ. 33, 394-401. doi: 10.1264/jsme2. ME18041

Nishihara, A., Haruta, S., McGlynn, S. E., Thiel, V., and Matsuura, K. (2018a). Nitrogen fixation in thermophilic chemosynthetic microbial communities depending on hydrogen, sulfate, and carbon dioxide. Microbes Environ. 33, 10-18. doi: 10.1264/jsme2.ME17134

O’Neill, A. H., Liu, Y., Ferrera, I., Beveridge, T. J., and Reysenbach, A. L. (2008). Sulfurihydrogenibium rodmanii sp. nov., a sulfur-oxidizing chemolithoautotroph from the Uzon Caldera, Kamchatka Peninsula, Russia, and emended description of the genus Sulfurihydrogenibium. Int. J. Syst. Evol. Microbiol. 58, 1147-1152. doi: 10.1099/ijs.0.65431-0

Padilla-Del Valle, R., Morales-Vale, L. R., and Ríos-Velázquez, C. (2017). Unraveling the microbial and functional diversity of Coamo thermal spring in Puerto Rico using metagenomic library generation and shotgun sequencing. Genomics Data 11, 98-101. doi: 10.1016/J.GDATA.2016.12.010

Panda, A. K., Bisht, S. S., De Mandal, S., and Kumar, N. S. (2016). Bacterial and archeal community composition in hot springs from Indo-Burma region, North-east India. AMB Express 6:111. doi: 10.1186/s13568-016-0284-y

Parks, D. H., Tyson, G. W., Hugenholtz, P., and Beiko, R. G. (2014). STAMP: statistical analysis of taxonomic and functional profiles. Bioinformatics 30, 3123-3124. doi: 10.1093/bioinformatics/btu494
Paul, S., Cortez, Y., Vera, N., Villena, G. K., and Gutiérrez-Correa, M. (2016). Metagenomic analysis of microbial community of an Amazonian geothermal spring in Peru. Genomics Data 9, 63-66. doi: 10.1016/j.gdata.2016.06.013

Pedron, R., Esposito, A., Bianconi, I., Pasolli, E., Tett, A., Asnicar, F., et al. (2019). Genomic and metagenomic insights into the microbial community of a thermal spring. Microbiome 7:8. doi: 10.1186/s40168-0190625-6

Pirajno, F. (2020). Subaerial hot springs and near-surface hydrothermal mineral systems past and present, and possible extraterrestrial analogues. Geosci. Front. 11, 1549-1569. doi: 10.1016/j.gsf.2020.04.001

Podar, P. T., Yang, Z., Björnsdóttir, S. H., and Podar, M. (2020). Comparative analysis of microbial diversity across temperature gradients in hot Springsfrom Yellowstone and Iceland. Front. Microbiol. 11:1625. doi: 10.3389/fmicb.2020. 01625

Power, J. F., Carere, C. R., Lee, C. K., Wakerley, G. L. J., Evans, D. W., Button, M., et al. (2018). Microbial biogeography of 1,000 geothermal springs in New Zealand. bioRxiv [preprint] doi: 10.1101/247759

Rabelo-Fernandez, R. J., Santiago-Morales, K., Morales-Vale, L., and RiosVelazquez, C. (2018). The metagenome of Caracolus marginella gut microbiome using culture independent approaches and shotgun sequencing. Data Brief 16, 501-505. doi: 10.1016/j.dib.2017.11.043

Rawlings, D. E., and Kusano, T. (1994). Molecular genetics of Thiobacillus ferrooxidans. Microbiol. Mol. Biol. Rev. 58, 39-55.

Rekadwad, B., and Khobragade, C. N. (2016). Bioinformatics data supporting revelatory diversity of cultivable thermophiles isolated and identified from two terrestrial hot springs, Unkeshwar, India. Data Brief 7, 1511-1514. doi: 10.1016/ j.dib.2016.04.038

Rudolph, B., Gebendorfer, K. M., Buchner, J., and Winter, J. (2010). Evolution of Escherichia coli for growth at high temperatures. J. Biol. Chem. 285, 1902919034. doi: 10.1074/jbc.M110.103374

Sahay, H., Yadav, A. N., Singh, A. K., Singh, S., Kaushik, R., and Saxena, A. K. (2017). Hot springs of Indian Himalayas: potential sources of microbial diversity and thermostable hydrolytic enzymes. 3 Biotech 7:118. doi: 10.1007/ s13205-017-0762-1

Sahoo, R. K., Kumar, M., Sukla, L. B., and Subudhi, E. (2017). Bioprospecting hot spring metagenome: lipase for the production of biodiesel. Environ. Sci. Pollut. Res. 24, 3802-3809. doi: 10.1007/s11356-016-8118-7

Sano, R., Kameya, M., Wakai, S., Arai, H., Igarashi, Y., Ishii, M., et al. (2010). Thiosulfate oxidation by a thermo-neutrophilic hydrogen-oxidizing bacterium, Hydrogenobacter thermophilus. Biosci. Biotechnol. Biochem. 74, 892-894. doi: 10.1271/bbb. 90948

Saxena, R., Dhakan, D. B., Mittal, P., Waiker, P., Chowdhury, A., Ghatak, A., et al. (2017). Metagenomic analysis of hot springs in Central India reveals hydrocarbon degrading thermophiles and pathways essential for survival in extreme environments. Front. Microbiol. 7:2123. doi: 10.3389/fmicb.2016. 02123

Schmieder, R., Edwards, R., and Bateman, A. (2011). Quality control and preprocessing of metagenomic datasets. Bioinformatics 27, 863-864. doi: 10. 1093/bioinformatics/btr026

Selvarajan, R., Sibanda, T., and Tekere, M. (2018). Thermophilic bacterial communities inhabiting the microbial mats of "indifferent" and chalybeate (iron-rich) thermal springs: diversity and biotechnological analysis. Microbiologyopen 7:e00560. doi: 10.1002/mbo3.560

Sharp, C. E., Brady, A. L., Sharp, G. H., Grasby, S. E., Stott, M. B., and Dunfield, P. F. (2014). Humboldt's spa: microbial diversity is controlled by temperature in geothermal environments. ISME J. 8, 1166-1174. doi: 10.1038/ismej.2013.237

Singh, Y., Gulati, A., Singh, D. P., and Khattar, J. I. S. (2018). Cyanobacterial community structure in hot water springs of Indian North-Western Himalayas: a morphological, molecular and ecological approach. Algal Res. 29, 179-192. doi: 10.1016/J.ALGAL.2017.11.023

Skirnisdottir, S., Hreggvidsson, G. O., Holst, O., and Kristiansson, J. K. (2001). Isolation and characterization of a mixotrophic sulfur-oxidizing Thermus scotoductus. Extremophiles 5, 45-51. doi: 10.1007/s007920000172

Sompong, U., Hawkins, P. R., Besley, C., and Peerapornpisal, Y. (2005). The distribution of Cyanobacteria across physical and chemical gradients in hot springs in Northern Thailand. FEMS Microbiol. Ecol. 52, 365-376. doi: 10.1016/ j.femsec.2004.12.007 
Sonne-Hansen, J., and Ahring, B. K. (1999). Thermodesulfobacterium hveragerdense sp. nov., and Thermodesulfovibrio islandicus sp. nov., two thermophilic sulfate reducing bacteria isolated from a Icelandic hot spring. Syst. Appl. Microbiol. 22, 559-564. doi: 10.1016/S0723-2020(99)80009-5

Soriano, B. M., Del Valle-Perez, L. M., Morales-Vale, L., and Rios-Velazquez, C. (2018). Datasets generated by shotgun sequencing of metagenomic libraries of the Guajataca water reservoir. Data Brief 21, 2531-2535. doi: 10.1016/j.dib. 2018.11.114

Takacs-Vesbach, C., Inskeep, W. P., Jay, Z. J., Herrgard, M. J., Rusch, D. B., Tringe, S. G., et al. (2013). Metagenome sequence analysis of filamentous microbial communities obtained from geochemically distinct geothermal channels reveals specialization of three aquificales lineages. Front. Microbiol. 4:84. doi: 10.3389/ fmicb.2013.00084

Takai, K., Kobayashi, H., Nealson, K. H., and Horikoshi, K. (2003). Sulfurihydrogenibium subterraneum gen. nov., sp. nov., from a subsurface hot aquifer. Int. J. Syst. Evol. Microbiol. 53, 823-827. doi: 10.1099/ijs.0. 02506-0

Tekere, M., Lötter, A., Olivier, J., Jonker, N., and Venter, S. (2011). Metagenomic analysis of bacterial diversity of Siloam hot water spring, Limpopo, South Africa. Afr. J. Biotechnol. 10, 18005-18012. doi: 10.5897/AJB11. 899

Thiel, V., Hügler, M., Ward, D. M., and Bryant, D. A. (2017). The dark side of the Mushroom Spring microbial mat: life in the shadow of chlorophototrophs. II. Metabolic functions of abundant community members predicted from metagenomic analyses. Front. Microbiol. 8:943. doi: 10.3389/fmicb.2017.00 943

Tomova, I., Stoilova-Disheva, M., Lyutskanova, D., Pascual, J., Petrov, P., and Kambourova, M. (2010). Phylogenetic analysis of the bacterial community in a geothermal spring, Rupi Basin, Bulgaria. World J. Microbiol. Biotechnol. 26, 2019-2028. doi: 10.1007/s11274-010-0386-7

Tripathy, S., Padhi, S. K., Mohanty, S., Samanta, M., and Maiti, N. K. (2016). Analysis of the metatranscriptome of microbial communities of an alkaline hot sulfur spring revealed different gene encoding pathway enzymes associated with energy metabolism. Extremophiles 20, 525-536. doi: 10.1007/s00792-0160846-6
Valverde, A., Tuffin, M., and Cowan, D. A. (2012). Biogeography of bacterial communities in hot springs: a focus on the actinobacteria. Extremophiles 16, 669-679. doi: 10.1007/s00792-012-0465-9

Varshney, P., Mikulic, P., Vonshak, A., Beardall, J., and Wangikar, P. P. (2015). Extremophilic micro-algae and their potential contribution in biotechnology. Bioresour. Technol. 184, 363-372. doi: 10.1016/j.biortech.2014.11.040

Wang, S., Hou, W., Dong, H., Jiang, H., Huang, L., Wu, G., et al. (2013). Control of temperature on microbial community structure in hot springs of the Tibetan Plateau. PLoS One 8:e62901. doi: 10.1371/journal.pone.0062901

Zhang, Y., Wu, G., Jiang, H., Yang, J., She, W., Khan, I., et al. (2018). Abundant and rare microbial biospheres respond differently to environmental and spatial factors in Tibetan hot springs. Front. Microbiol. 9:2096. doi: 10.3389/fmicb. 2018.02096

Zhou, E. M., Adegboruwa, A. L., Mefferd, C. C., Bhute, S. S., Murugapiran, S. K., Dodsworth, J. A., et al. (2020). Diverse respiratory capacity among Thermus strains from US Great Basin hot springs. Extremophiles 24, 71-80. doi: 10.1007/ s00792-019-01131-6

Conflict of Interest: The authors declare that the research was conducted in the absence of any commercial or financial relationships that could be construed as a potential conflict of interest.

Publisher's Note: All claims expressed in this article are solely those of the authors and do not necessarily represent those of their affiliated organizations, or those of the publisher, the editors and the reviewers. Any product that may be evaluated in this article, or claim that may be made by its manufacturer, is not guaranteed or endorsed by the publisher.

Copyright (c) 2021 DeCastro, Escuder-Rodríguez, Becerra, Rodríguez-Belmonte and González-Siso. This is an open-access article distributed under the terms of the Creative Commons Attribution License (CC BY). The use, distribution or reproduction in other forums is permitted, provided the original author(s) and the copyright owner(s) are credited and that the original publication in this journal is cited, in accordance with accepted academic practice. No use, distribution or reproduction is permitted which does not comply with these terms. 